\title{
Exploring the Double-Sided Effect of Information
}

\author{
Asymmetry and Uncertainty in Mergers and Acquisitions
}

December 2016

Mathieu Luypaert and Tom Van Caneghem*

\begin{abstract}
We examine the joint effect of bidder and target information asymmetry and uncertainty on the payment consideration (i.e., cash vs. stock) as well as subsequent wealth effects (i.e., abnormal returns and division of gains) in a large sample of acquisitions with both listed and private targets. In line with a risk-sharing argument, we find that acquisitions of targets characterized by higher uncertainty are more likely to be settled with stock. However, higher target information asymmetry also increases the likelihood of a cash payment, consistent with bidders strategically exploiting superior information gathered during the due diligence process. Acquirers of more opaque targets realise higher abnormal returns, obtain a larger fraction of total acquisition gains, and avoid sharing these gains with target shareholders by offering cash.
\end{abstract}

Keywords: mergers, acquisitions, information asymmetry, uncertainty, method of payment, announcement returns

\footnotetext{
We thank Raghavendra Rau (Editor) and an anonymous referee for very helpful comments. We also thank Evy Bruyland, Katrien Craninckx, Wouter De Maeseneire, Denis Gromb, Nikolaos Karampatsas, Andrew Karolyi, Diana Knyazeva, Pascal Maenhout, Massimo Massa, Bill Megginson, Urs Peyer, Christophe Spaenjers, Karin Thorburn and participants in the Annual Conference of the Midwest Finance Association (March 2013, Chicago) and the European Financial Management Association (June 2013, Reading) for useful comments on an earlier draft of this article.

* Mathieu Luypaert is Associate Professor at Vlerick Business School. Tom Van Caneghem is Associate Professor at KU Leuven and Universiteit Antwerpen.
} 
It has been documented in the finance literature that the extent of information asymmetry and uncertainty in mergers and acquisitions (M\&As) strongly affects deal attributes as well as the wealth generated by both parties (e.g., Chemmanur et al., 2009; Officer et al., 2009; Moeller et al., 2007; Eckbo et al., 1990; Fishman, 1989; Hansen, 1987). In the specific context of M\&A negotiation, a double-sided information problem arises as both bidder and target are uncertain about the other's value. The return realized by the acquiring company depends upon an accurate assessment of target value and accompanying synergistic effects. Similarly, the wealth effect for target shareholders in stock transactions is contingent upon acquirer value and potential synergistic gains.

In this paper, we distinguish between information asymmetry and uncertainty as two distinct concepts. Information asymmetry relates to the extent of information availability. During an extensive due diligence process, the bidder is able to gather superior information about the target which implies that the extent of information asymmetry is not equal across all market participants. As such, the bidder is likely to strategically exploit his information advantage during the M\&A negotiation process. Uncertainty, in contrast, relates to the volatility of a firm's underlying fundamentals, which is symmetric across market participants and cannot be reduced regardless of effort. Uncertainty therefore complicates a correct value assessment by all market participants.

We investigate the economic channels through which target and bidder information asymmetry and uncertainty jointly affect the method of payment and subsequent wealth effects in M\&As. A first channel includes the protection against overpayment resulting from adverse selection by offering stock, making the value of the offer contingent upon market reactions (Hansen, 1987). A second driver relates to the strategic use of superior information by the bidder on the target company compared to other market participants (cf. supra). Bidders might strategically exploit the resulting superior bargaining position by imposing their 
preferred method of payment (being cash) to attract a larger fraction of total M\&A gains. Bruner (2004) refers to private information as the "sweet spot" for acquirers and relates it to lower competition, more advantageous pricing and better opportunities for deal tailoring. Third, bidders having private information concerning their own value, may try to benefit from their information advantage by offering stock when they are overvalued (Rhodes-Kropf and Viswanathan, 2004; Shleifer and Vishny, 2003). McSweeney (2012) explicitly refers to the decision of using stock payments in M\&As as a trade-off between reducing the downside for bidding companies of overvaluing targets, and increasing the extent of information asymmetry and uncertainty for targets in assessing the offered price.

In a sample of US M\&A deals, consisting of 1725 listed and 1810 private targets, initiated by publicly quoted acquirers during 1994-2001, and using a variety of information asymmetry proxies (analyst coverage, analyst forecast properties, media coverage, listing status, firm size, as well as compound indices), we find evidence consistent with bidders strategically exploiting their superior bargaining power (resulting from the superior information gathered during the due diligence process) to attract a larger fraction of M\&A gains. That is, we show that more opaque targets have a higher likelihood to be offered cash payments. In addition, acquirers earn higher abnormal returns and a larger fraction of total M\&A gains if the target is characterized by higher information asymmetry. Thus, to avoid sharing these gains with target shareholders, bidders are more likely to opt for cash payments if the target is more opaque.

In contrast, targets with a value that is more uncertain to all market participants (proxied by implied volatility, idiosyncratic return volatility, as well as a compound index), are more likely to receive stock offers. As mentioned earlier, offering stock allows the bidder to share the risk of overpayment (that might result from uncertainty) with target shareholders. We further demonstrate that bidders characterized by higher uncertainty and information 
asymmetry are more likely to engage in market-timing behaviour through a higher incidence of stock swaps. In the literature, several arguments have been advanced to explain target's willingness to accept (overvalued) stock (e.g., bidders can explicitly pay target's top management for their consent (Hartzell et al., 2004), targets tend to over-estimate the value of synergistic benefits in an overvalued market (Kropf and Viswanathan, 2004) or selling shareholders prefer to postpone taxes on capital gains through stock offers (Brown and Ryngaert, 1991)). It is interesting to note that our results also indicate that the previously documented negative stock price reaction upon stock swaps (e.g., Travlos, 1987; Huang and Walkling, 1987) is further strengthened by bidder information asymmetry and uncertainty. This finding indicates that investors recognize the opportunities for bidders to exploit temporary overvaluation. When dividing our sample in two-way terciles in terms of bidder and target information asymmetry (uncertainty), we show that the impact of bidder and target opacity and uncertainty act together. For example, when focusing on the effect of information asymmetry, we find that the likelihood of a cash payment is highest if the target is located in the top tercile (highest information asymmetry) while the bidder is located in the bottom tercile (lowest information asymmetry).

Our study contributes to the existing literature in several ways. First, we focus on the joint impact of both sides of the double-sided information problem in M\&As, while prior literature typically considers only one side of the problem (either the target (e.g., Officer et al., 2009; Reuer et al., 2004) or the bidder (e.g., Duchin and Schmidt, 2013; Lin et al., 2009; Moeller et al., 2007; Travlos, 1987) side). Chemmanur et al. (2009), who focus on the tradeoff between the risk of overpayment and the probability of an unsuccessful bid, provide a notable exception. They show that cash payments deter competing offers in a setting of proprietary target information, but only in models where they consider both target and bidder private information. Their findings therefore illustrate the need for considering both sides of 
the information problem (i.e., considering only one side may bias findings). Second, we make a clear distinction between information asymmetry and uncertainty, and show that they have different effects on the method of payment and wealth effects in M\&As. Third, prior studies typically ignore the second economic channel (i.e., strategic use of superior information by the bidder), which requires a careful analysis of the division of gains between both parties. While some studies have analysed the distribution of M\&A wealth effects between bidders and targets (e.g., Ahern, 2012; Bauguess et al., 2009), they fail to consider the effect of uncertainty and information asymmetry between both parties. Our study fills this void in the literature.

The remainder of the article is organized as follows. In Section I, we discuss prior literature and develop our hypotheses. Our sample and methodology are introduced in Section II. In Section III, we present and discuss our results. Finally, we summarize our main conclusions in Section IV.

\section{Hypotheses}

M\&As represent a unique setting to study the role of information asymmetry and uncertainty as it might affect both bidder's and target's value. The quality and quantity of the information available to both parties are likely to influence important choices relating to the type of bid, the offer premium and the means of payment (Raman et al., 2013). In addition, investors' reactions upon deal announcement will reflect both frictions as well as value-creating opportunities resulting from either inferior or superior information on the counterparty.

In this section, we present our hypotheses on how the aforementioned double-sided problem of asymmetric information and uncertainty influences payment methods and acquirer (relative) returns, building upon three different economic channels. We first analyse target opacity and how bidders might protect against overpayment by offering stock payments. In 
addition, we focus on the strategic exploitation of superior information obtained by bidding firms about the target's value, compared to other market participants. Next, we consider uncertainty and private information about the bidder's value and investigate the potential use of relatively overvalued stock to pay for their target companies. An overview of the different hypotheses (and the proxies used to capture target and acquirer information asymmetry and uncertainty) is presented in Table I.

$<$ Insert Table I $>$

\section{A. Target Information Asymmetry and Uncertainty}

In his seminal paper, Hansen (1987) argues that a lemons problem arises in M\&A transactions when target companies possess proprietary information about their own value. The target is expected to only accept an acquisition offer if the bidder offers more than the actual target value. The bidding firm can protect itself against adverse selection by offering a payment in stock as the value of such an offer is contingent upon market reactions between the M\&A announcement and the completion of the transaction (see also Officer, 2009; Reuer et al., 2004; Eckbo et al., 1990; Fishman, 1989). In an efficient market, the stock price reaction will depend upon investors' expectations of future synergy realization. The acquirer's stock price will drop if the market considers the M\&A to be a value-destroying decision, resulting in a lower offer for target shareholders. As such, bidders can shift part of the risk about the target's value through stock offers.

These desirable contingent-pricing characteristics are expected to matter especially in settings characterized by greater information asymmetry and uncertainty. Hansen (1987) predicts that the impact of information asymmetry, and hence, the contingent pricing effect of a stock offer, is higher if the target is relatively larger compared to the acquirer. Supportive findings for this prediction have been presented by Faccio and Masulis (2005) and Martynova and Renneboog (2009), among others. Reuer et al. (2004) study the role of contingent 
payments in international M\&As and show that firms lacking acquisition experience typically opt for contingent payments when purchasing targets in industries that are more difficult to value (e.g., high tech).

The contingent-pricing arguments suggest that acquiring companies will avoid cash offers when targets are more challenging to value correctly. This is reflected in the following hypothesis:

Hypothesis 1 (H1): Acquiring firms are less inclined to opt for cash payments if targets are characterized by higher information asymmetry and/or uncertainty.

Next, the extent and quality of public information about the target's value is also likely to affect its bargaining position in M\&A transactions. A lack of investor cognizance could cause stocks to trade below their fundamental value, resulting in inferior negotiation power (Kelly and Ljungqvist, 2011; Barber and Odean, 2008; Doukas et al., 2005; Chung and Jo, 1996; Brennan and Subrahmanyan, 1995). Firms interested in acquiring a target obtain superior information during an extensive due diligence process. As part of the negotiation process, the target's management is likely to allow bidders to access management accounts and other inside information (Raman et al., 2013). The information gap between these informed bidders and other market participants is expected to be larger when targets are more opaque. In addition, the potential information asymmetry in the market implies the existence of a firstmover advantage, reducing the likelihood of competing offers (Bruner, 2004). This creates a relatively stronger negotiation position that can be exploited by the informed bidder through lower offer prices, leading to higher abnormal acquirer returns around the M\&A announcement. In a similar vein, Capron and Shen (2007) argue that limited information on private compared to publicly quoted firms, creates more value creating opportunities for 
exploiting private information. In line with our arguments, they state that bidders prefer low information asymmetry vis-à-vis targets, but high information asymmetry vis-à-vis competing bidders in order to fully benefit from the private information advantage. Also, Mantecon (2008) shows that acquiring firms gain when acquiring private firms because of the private target's relatively weaker bargaining position due to informational and agency problems and costly access to external capital.

This reasoning does not necessarily mean that targets characterized by higher information asymmetry will realize lower premia upon deal announcement. Although takeover prices might be below those for more transparent targets, the difference between the offer price and the stand-alone value of the targets (i.e., the premium) might be at the same level or even higher due to the relatively low stand-alone value of opaque targets before the M\&A. This explains why targets are likely to accept these offers. Accordingly, the M\&A might constitute a value creating strategy for both bidder and target, but the stronger bargaining position should allow acquirers to obtain a larger fraction of total M\&A gains.

Rational bidders should try to avoid sharing the incremental gains with target shareholders. This can be achieved by offering fixed cash offers. The cost of such an offer is independent of the investor's reaction upon deal announcement. Hence, the additional gains from a more positive assessment of the M\&A by the market will not have to be shared with target shareholders. In stock swaps, on the other hand, the total amount paid to target shareholders will be higher if acquirer investors react more positively to the announced transaction. Therefore, we expect bidders to offer cash payments especially when the value to other outside investors is less visible.

As these arguments are built specifically upon the notion of asymmetric distribution of information between the more informed bidding company and other market participants 
(instead of symmetric uncertainty), our second hypothesis solely refers to the impact of information asymmetry. The aforementioned considerations lead to the following predictions:

Hypothesis $2 a(H 2 a)$ : Acquiring firms are more inclined to opt for cash payments if targets are characterized by higher information asymmetry.

Hypothesis $2 b(\mathrm{H} 2 b)$ : Acquirers realize higher returns upon announcement of acquisitions of targets characterized by higher information asymmetry.

Hypothesis 2c (H2c): Acquirers earn a larger fraction of total M\&A gains if targets are characterized by higher information asymmetry.

\section{B. Acquirer Information Asymmetry and Uncertainty}

Along with target opacity, also information asymmetry and uncertainty concerning the acquirer's value might drive the payment consideration as it offers opportunities to exploit short-term overvaluation. Several authors indeed provide evidence of such market-timing behaviour in firms' financing decisions (e.g., Chang et al., 2006; Baker and Wurgler, 2007; Graham and Harvey, 2001; Loughran and Ritter, 1995; Ritter, 1991; Myers and Majluf, 1984). A key ingredient for exploiting misvaluation is the existence of differences in the information sets of managers and financial markets concerning the value of the firm (Chang et al., 2006). Shleifer and Vishny (2003) develop a theoretical model of M\&As under the assumption that managers act rational, understand stock market inefficiencies and take advantage of them. They argue that overvalued acquirers try to benefit from short-term overvaluation of their shares by buying relatively less overvalued targets in stock paid transactions. Empirical findings by Dong et al. (2006) and Rhodes-Kropf et al. (2005) confirm the theoretical prediction that overvaluation is an important motive for firms to make stock acquisitions. Temporary deviations of stock prices from their fundamental values are more likely the higher 
the volatility of stock prices - and hence uncertainty - and the extent of asymmetric information (e.g., Baker and Wurgler, 2007; Zhang, 2006). That is why we expect to observe more stock transactions if the acquirer's value is more unclear/uncertain to outside investors.

Several arguments have been advanced to explain target's willingness to accept overvalued acquirer stock. First, bidders can explicitly pay target's top management for their consent. These benefits could take the form of either increased financial wealth or attractive positions in the newly combined company (Hartzell et al., 2004). As such, target management might compromise the interest of their own shareholders in pursuit of these benefits. Next, Rhodes-Kropf and Viswanathan (2004) model target's behaviour and illustrate that targets are likely to accept overvalued stock offers because they tend to over-estimate the value of synergistic benefits in an overvalued market. In addition, Brown and Ryngaert (1991) argue that selling shareholders can postpone taxes on capital gains through stock offers, while the shares swapped are valued by the target as if they were offered by the average bidder.

This market-timing behaviour of acquirers is likely to affect investors' reaction upon deal announcement. By offering a stock payment, managers of acquiring firms signal to the market that they are overvalued (Myers and Majluf, 1984). Consequently, several studies provide evidence of lower acquirer announcement as well as long-term returns in M\&As paid for with stock (e.g., Loughran and Vijh, 1997; Travlos, 1987). However, the argument of temporary stock market overvaluation rests on the assumptions of asymmetric information and uncertainty. Hence, we expect to observe a stronger negative reaction of investors to the announcement of stock offers initiated by more opaque acquirers. Consistent with this prediction, Moeller et al. (2007) show that acquirer abnormal returns are negatively related to information asymmetry and diversity-of-opinion proxies for stock offers, but not for cash offers. Following the above outlined arguments, we conjecture the following: 
Hypothesis 3a (H3a): Acquirers are more inclined to opt for stock payments if they are characterized by higher information asymmetry and/or uncertainty.

Hypothesis $3 b(H 3 b)$ : The negative impact of stock payments on acquirer announcement returns is aggravated by higher acquirer information asymmetry and/or uncertainty.

\section{Sample and Methodology}

\section{A. Sample}

Through the Thomson Financial SDC Platinum database, we select a sample of M\&As between two publicly quoted US firms during 1994-2011. Our sample period captures the M\&A waves of the second half of the 1990s and that of the mid-2000s. We impose the following selection criteria to obtain our final sample. First, we only consider deals with a real change in control over the target's resources. Hence, the total stake that the bidder aims to achieve in the target post-M\&A has to exceed $50 \%$ for the deal to be retained in our sample. Furthermore, we drop all deals where the bidding firm already owned $50 \%$ of target stock before the M\&A announcement date. Second, we exclude all financial firms (i.e., primary SIC code starting with 6). Third, we only include deals where the method of payment is captured by SDC (either cash, stock or a combination of both). Finally, we require both target and acquirer to have accounting and stock price data available on, respectively, Compustat and CRSP. These selection criteria leave us with a sample of 1725 M\&As.

Next, we construct a second sample of acquisitions of private targets by listed bidders. We impose exactly the same selection criteria and only include private targets with a known deal value on SDC. This results in an additional sample of 1810 acquisitions.

The deal characteristics of our sample are presented in Table II. We observe that $85.33 \%(94.81 \%)$ of all announced acquisitions of public (private) targets in our sample are completed. We further notice that $23.65 \%$ of all public-public transactions are characterized 
as tender offers, $8.06 \%$ were opposed by target management (i.e., hostile offers) and $8.75 \%$ were countered by a rival offer. Not surprisingly, tender offers $(0.28 \%)$, hostile M\&As $(0.06 \%)$ and deals with rival offers $(0.39 \%)$ only represent a marginal fraction of acquisitions of private targets. Table II also reveals that $39.07 \%(34.14 \%)$ of public (private) targets operate in the same industry as their acquirer (four-digit SIC codes). Finally, $42.32 \%$ of all public-public M\&As are compensated with cash, while $34.03 \%$ are pure stock offers. Hence, $23.65 \%$ of public-public M\&As are paid with a combination of different instruments. In the sample of private targets, $46.35 \%$ are stock offers, $24.64 \%$ are mixed payments and $29.01 \%$ are pure cash payments.

$<$ Insert Table II $>$

\section{B. Empirical Proxies for Information Asymmetry and Uncertainty}

The ambiguity of investors with respect to a firm's value might stem from two important sources (Lu et al., 2010; Zhang, 2006). First, the extent of information availability determines the ease and quality of company valuation. If information is asymmetrically distributed over market participants, adverse selection costs might arise and superior information can be strategically exploited. These differences might exist between insiders and outsiders of the firm as well as between different outside market participants. Second, the volatility, and hence uncertainty, of a firm's underlying fundamentals complicates a correct value assessment by all participants in the market. The remainder of this section describes the empirical proxies that we use to capture these distinct concepts.

We first present our proxies for information asymmetry. As there is no single comprehensive measure of information asymmetry, we analyse multiple proxies that have been used extensively in prior literature. We start by studying the impact of analyst coverage. Financial analysts synthesize and aggregate complex information that would otherwise not be 
easily understandable to less sophisticated investors (Chang et al., 2006). Moreover, they collect information that is not widely known by market participants and disseminate this information to investors through the publication of reports containing earnings forecasts and stock recommendations. Consistent with financial analysts adding value in the market by reducing information asymmetry, empirical research has shown that higher analyst coverage leads to a more rapid incorporation of information in stock prices (Brennan et al., 1993), higher liquidity (Brennan and Subrahmanyan, 1995; Irvine, 2003), a lower cost of raising equity capital (Bowen et al., 2008), and less earnings management (Yu, 2008). In addition, Mola et al. (2013) illustrate that financial analysts play an important role in bringing covered stocks to the attention of investors. Limited investor attention could cause stocks to trade below their fundamental value, and hence, lead to inferior negotiation power in M\&A transactions (e.g., Kelly and Ljungqvist, 2011; Barber and Odean, 2008). We use the I/B/E/S database to determine the number of analyst recommendations for the last month of the fiscal year preceding the M\&A announcement. In line with Chang (2006) and Yu (2008), among others, we assume that firms that are not covered by I/B/E/S have no analyst coverage (analyst coverage equals zero). We calculate relative analyst coverage by normalizing the number of analyst recommendations by firm size and include its inverse in our regression models.

The quality of the information provided by financial analysts may also play an important role. We capture the informativeness of analyst forecasts using two proxies. First, we consider analyst forecast error by determining the absolute value of the difference between the median earnings-per-share (EPS) estimate by analysts during the final month of the year preceding the M\&A announcement and its actual value, scaled by the stock price. Second, we compute the dispersion in analyst forecasts as the standard deviation in analyst EPS estimates, scaled by the firm's stock price. ${ }^{1}$ Since disagreement among analysts can be induced by a lack

\footnotetext{
${ }^{1}$ Consequently, this measure can only be calculated for firms followed by at least two financial analysts.
} 
of publicly available information about the firm, it has been widely used in prior research as a proxy for information asymmetry (e.g., Chatterjee et al., 2012, Chemmanur et al., 2009; Krishnaswami and Subramaniam, 1999). ${ }^{2}$

We use media coverage as a fourth measure of asymmetric information. The media serves as one of the most important channels through which information is disseminated to potential investors. Press coverage is found to drive trading, alleviate informational frictions and affect security pricing (Tetlock, 2010; Fang and Peress, 2009; Barber and Odean, 2008). We hand-collected data on media coverage through the Factiva database. We follow Ahern and Sosyura (2014) by using the number of articles in all English-language media sources included in Factiva's category of major news and business publications in the year preceding the acquisition announcement. This includes a large number of publications, such as USA Today, The Wall Street Journal, The New York Times, and many others. To make sure that we count substantive articles, we eliminate articles with fewer than 50 words and articles categorised by Factiva as recurring pricing and market data. Similarly to analyst coverage, we also normalize media coverage by firm size and consider its inverse.

A fifth measure capturing asymmetric information is the listing status of the target company. One of the crucial differences between private and public firm acquisitions is the quantity and quality of information available on the target company (Officer, 2009; Mantecon, 2008; Capron and Shen, 2007). Enhanced disclosure requirements, greater investor attention, scrutiny by financial analysts and larger media coverage make public targets considerably less opaque than private targets.

\footnotetext{
${ }^{2}$ However, one criticism of analyst dispersion as a measure of information asymmetry is that dispersion among analysts might be high even though all market participants are well informed, because of more volatile earnings and differing beliefs among market participants about the firm's future performance (Barron et al., 1998). Nevertheless, our empirical results regarding target analyst dispersion, presented in Section III, are more in line with the other proxies of information asymmetry rather than uncertainty.
} 
Finally, as larger firms are generally more visible and less informationally opaque compared to smaller firms, we also consider firm size to be a proxy for information availability. We capture size by the natural logarithm of the firm's total assets. Next to target and bidder absolute size, we also include the relative size of target compared to the bidder in all models.

Next, we consider two measures of uncertainty. We first analyse the impact of implied volatility. This is a forward-looking risk measure reflecting the future volatility of returns over the remaining lifetime of an option. Following Bargeron et al. (2014) and Duchin and Schmidt (2013), we collect standardized implied option volatilities of 91-day at-the-money (ATM) options from the estimated volatility surface in the Optionmetrics database. We consider the average implied volatility of ATM call and ATM put options and avoid effects of information leakage before the M\&A announcement by focussing on the median daily implied volatility from 80 days through 51 days before the acquisition announcement (i.e., final 30 trading days of the estimation period in the event study). Because coverage of Optionmetrics starts in 1996, our sample period is restricted for this additional proxy. We were able to collect acquirer implied volatility data for 850 transactions, while target implied volatility is known for only 641 transactions. A second proxy that we use is the idiosyncratic return volatility of target and acquirer, measured as the standard deviation of the marketadjusted residuals of daily stock returns during a 200-day estimation window (i.e., 250 days until 51 days before the announcement). This volatility measure has the advantage of only capturing firm-specific risk factors and has been applied before by Officer et al. (2009) to proxy for difficulty of valuation of target companies in M\&A transactions.

Additionally, we construct composite indices of asymmetric information and uncertainty aggregating the aforementioned proxies (see also Lin et al., 2009). We normalize each of the individual measures and compute their average value. We first consider two 
indices capturing information asymmetry. A first index is calculated based upon the inverse of analyst coverage, analyst forecast dispersion, analyst forecast error and the inverse of media coverage. A second asymmetric information index also incorporates the inverse of firm size next to all measures included in the first index. Finally, we compute an index measuring uncertainty based upon both implied and idiosyncratic volatility.

Table III provides an overview of descriptive statistics on target and acquirer characteristics, including our asymmetric information and uncertainty proxies. Analyst coverage in our sample is found to be significantly higher for acquirers compared to targets. The average (median) number of analysts following acquirers equals 10.31 (8.00), while it amounts to 5.08 (3.00) for target firms. Differences in analyst forecast dispersion and forecast errors are only found to be significant when looking at medians. The average (median) number of articles in the pre-M\&A year equals 352.99 for acquirers and only 25.66 for targets. Implied volatility is found to be higher for targets (average of 57.26\%) compared to acquirers (46.22\%). The same holds for idiosyncratic stock return volatility (4.21\% versus $3.05 \%)$. Not surprisingly, acquirers are significantly larger than their targets, both in terms of total assets as well as market capitalization. Table III further reports that the median bidder's market-tobook ratio of equity (2.98) in the public-public sample lies significantly above that of their targets (2.05), while the difference in average market-to-book ratios is not found to be significant. We also observe that acquirers typically have lower cash levels, more debt, higher profitability and less R\&D expenses than their targets. When comparing with the subsample of public-private deals, we observe that acquirers of private targets are typically smaller than those of public targets, have higher market-to-book ratios, cash levels and R\&D expenses, while they are found to have lower debt and profitability levels. 


\section{Results}

In this section, we discuss our empirical results. We start by analysing the antecedents of the M\&A payment choice and focus on the relative strength of target and acquirer opacity in jointly determining the type of payment. Next, we explore the role of information asymmetry and uncertainty in determining acquirer abnormal returns, as well as the division of M\&A gains between targets and acquirers.

\section{A. Choice of payment consideration}

The binary probit regression models in Table IV investigate the determinants of the likelihood of fixed cash offers versus offers that are at least partly compensated with stock (i.e., full stock and mixed payments). The dependent variable equals one if the bidder offers an all-cash payment and zero otherwise. We focus on the explanatory role of information asymmetry on both target and acquirer (with regard to testing $\mathrm{H} 1$ and $\mathrm{H} 2 \mathrm{a}$ ). We estimate separate regression models for each proxy of information asymmetry and control for target and acquirer size as well as the relative size of target versus acquirer. ${ }^{3}$ In addition, we add several control variables that have been shown to determine the M\&A payment choice in prior literature. The type of deal is controlled for by including dummy variables capturing respectively whether it is a tender, a hostile or an industry-related offer (at 4-digit SIC level). We also take into account acquirer toeholds in the target before the acquisition announcement. Next, we include several target and acquirer characteristics that might be linked to the underlying financing decision. While stock payments generally imply the issuance of new shares (or using shares in treasury),

\footnotetext{
${ }^{3}$ Target and bidder size are included in all regressions except for the models with information asymmetry index 2 , because size has been incorporated as one of the components of that index. The regression with the private target dummy only includes the acquirer size as the value of total assets for the private targets is not known.
} 
cash offers are more likely to be financed with available cash reserves or new loans (e.g., Harford et al., 2009; Martynova and Renneboog, 2009). In particular, we look at the target's and bidder's market-to-book ratio of equity, cash ratio, debt ratio, profitability, and R\&D intensity. Following Ahern (2012), we also account for relative scarcity by including industry value added and industry variability of profitability. This allows us to distinguish between effects of information asymmetry (i.e., focus of our paper) and relative scarcity. Industry value added is captured through the Use and Make tables provided by the US Bureau of Economic analysis (BEA). ${ }^{4}$ Specifically, we divide the value added of each industry by its total output. For this purpose, we convert six-digit North American Industry Classification System (NAICS) codes provided by SDC to IO industry codes using the concordance tables provided by the BEA. Variability of profitability within the industry is calculated as the standard deviation of EBITDA/total assets in the target's and acquirer's four-digit SIC industry. Finally, we add year dummies in all our models. A check of the correlations among the various explanatory variables reveals that none are too highly correlated (pairwise correlations do not exceed 0.5). The variance inflation factors never surpass five. All regressions are run using White's heteroscedasticity-corrected standard errors. A detailed summary of the definitions of all explanatory variables can be found in Appendix A.

<Insert Table IV>

The results in Table IV reject the predictions regarding information asymmetry in H1 but instead are consistent with $\mathrm{H} 2 \mathrm{a}$. We observe that M\&As of targets characterised by higher information asymmetry are more likely to be all-cash offers. The coefficients of all asymmetric information proxies are significantly positive, except for the inverse of media coverage. In addition, smaller targets are typically settled through cash offers. These findings

\footnotetext{
${ }^{4}$ As these reports are produced each five years, we choose to work with the 2002 report, splitting our sample period roughly in half.
} 
suggest that higher target information asymmetry increases the acquirer's bargaining power in the M\&A process, which is likely to result in higher expected value creation around the deal announcement. Consequently, bidders will be more inclined to opt for fixed cash payments. The impact of information asymmetry in explaining acquirer wealth effects will be investigated in detail in section III.B. In line with our theoretical predictions, H2a only holds for the proxies of information asymmetry. The measures of uncertainty are found to negatively affect the likelihood of cash payments. This finding does support $\mathrm{H} 1$ and illustrates that stock payments could resolve the acquirer's concerns when uncertainty about the target's value is high, by sharing the risk with target shareholders. In this respect, our findings confirm the conclusions of Officer et al. (2009). However, the contribution of our findings is that we demonstrate opposite effects when considering asymmetric information instead of symmetric uncertainty.

Consistent with $\mathrm{H} 3$, acquirers with a more uncertain value are more likely to opt for stock payments. The coefficients of all acquirer uncertainty measures are negative and highly significant (at $1 \%$ level). The second composite acquirer information asymmetry index and analyst forecast dispersion also have a significantly negative effect on the probability of cash offers. ${ }^{5}$ In addition, larger acquirers are more likely to pay in cash. In sum, these findings suggest that higher information asymmetry and uncertainty about the bidder's value enlarge the opportunities to exploit relative overvaluation in the market by offering stock payments.

Concerning the control variables, we find that cash payments are more likely in tender offers and hostile offers. Offering cash increases the probability of acceptance in these types of transactions (e.g., Martin, 1996; Faccio and Masulis, 2005). The likelihood of stock offers is found to be greater in industry-related transactions. Taking into account shareholder

\footnotetext{
${ }^{5}$ Surprisingly and in contrast to our other proxies for information asymmetry and uncertainty, we observe a significantly positive coefficient of acquirer analyst forecast error on the likelihood of cash payment. This suggests that a higher forecast error by analysts does not increase the likelihood of market-timing behaviour.
} 
investment preferences, target shareholders could be more inclined to invest in the shares of the newly combined firm and, hence, to accept stock offers if the acquiring firm is operating in the same industry as the target firm. Many studies indeed provide evidence of an increased probability of stock payment in industry-related M\&As (e.g., Faccio and Masulis, 2005). Acquirer toeholds are negatively related to the use of cash payments. This is in line with stock being used when target uncertainty is lower. Regarding the firm characteristics, we observe that bidders with high market-to-book ratios tend to pay with shares, while high acquirer profitability incites more cash offers. The level of acquirer $R \& D$ expenses has a negative impact on the likelihood of cash payments, which is consistent with acquirers preferring stock payments if their own value is more uncertain. We further notice that cash offers are more likely to occur if value added in the target industry and the standard deviation of profitability in the acquirer's industry are low.

In addition, we examine the robustness of our results by estimating alternative regression models (see Appendix B). First, we estimate logit instead of binary probit regression models (columns 1-3). Second, we analyse ordered probit models where the dependent variable equals zero for all-stock offers, one for mixed offers and two for all-cash offers (columns 4-6). Finally, we estimate OLS regressions with the fraction of cash in the total price offered as dependent variable (columns 7-9). ${ }^{6}$ The results in Appendix B confirm our earlier findings, demonstrating that the likelihood of full cash payments as well as the fraction of cash in the total payment consideration are higher in acquisitions of informationally more opaque and less uncertain targets. Acquirers are more inclined to opt for a higher fraction of stock if they are affected by higher information asymmetry and uncertainty.

\footnotetext{
${ }^{6}$ The exact fraction of cash in the total offer price is known for 845 out of 922 deals for which the asymmetric information indices are available, and for 335 out of 402 deals with a known uncertainty index for both parties.
} 
In Table $\mathrm{V}$ we investigate the relative strength of target and acquirer information asymmetry and uncertainty in determining the likelihood of cash payments, by dividing the sample in two-way terciles. The split-up in asymmetric information terciles is based upon the second information asymmetry index (i.e., including all proxies). The univariate results in Panel A show that the fraction of full cash payments in acquisitions of targets in the top tercile of information asymmetry by acquirers in the bottom tercile equals $62.90 \%$. This percentage drops to only $31.43 \%$ in the opposite situation. If both target and acquirer are in the highest tercile, we observe $37.91 \%$ cash offers. Finally, the fraction of cash offers if both firms are part of the bottom tercile amounts to $49.38 \%$. We also investigate the joint impact of both forces by including four dummy variables in our multivariate regression models. These dummy variables capture the combined presence of targets and acquirers in the top and bottom terciles of information asymmetry. The results in Panel B of Table V reveal that the likelihood of cash payments is significantly higher if targets are characterized by high and bidders by low information asymmetry. These results provide support for $\mathrm{H} 2 \mathrm{a}$ and $\mathrm{H} 3$ and illustrate that both forces act together.

When dividing the sample based upon the uncertainty index, we observe the lowest fraction of cash-paid transactions (only 16.47\%) if target's and acquirer's uncertainty is high. The multivariate results confirm that the probability of cash payments is significantly higher (lower) if the value of both firms is more (less) uncertain. These results confirm that acquirers prefer to share risk through stock offers if target uncertainty is high (supporting H1). In addition, bidders are more inclined to exploit overvaluation of their stock when their value is more uncertain (in line with H3). These results confirm that both drivers act jointly and do not offset each other.

<Insert Table V> 


\section{B. Acquirer abnormal returns}

We apply the event study methodology to analyse shareholder value that is being created through the M\&As in our sample. Abnormal acquirer and target returns are computed as the difference between realized returns and expected returns. Expected returns are calculated using the market model, which is estimated during a clean period $[-250,-51]$ relative to the event date (day 0). We use the S\&P 500 index as market index and study the significance of these abnormal returns using the standard test developed by Dodd and Warner (1983). The average cumulative abnormal returns over the event windows $[-10,+10],[-5,+5],[-1,+1]$ and $[-1,0]$ as well as the abnormal return on the event day itself are presented in Panel A of Table VI. Consistent with prior literature (e.g., Fuller et al., 2002; Chang, 1998), we show that bidding firms realize small but significantly negative abnormal returns when acquiring public targets, while realizing positive returns at the announcement of private target acquisitions. These returns amount to respectively $-1.68 \%$ and $1.75 \%$ on average over the three-day window surrounding the announcement $([-1,+1])$. The average target CAR (that can only be measured in public-public M\&As) equals $24.81 \%$ over the same window. The largest oneday shock for targets as well as acquirers takes place on the announcement date itself. Over the long $[-10,+10]$ window, acquirers of public targets lose $-2.53 \%$ while those of private targets realize insignificant returns. Target firms earn $29.60 \%$ on average over this longer window.

\section{$<$ Insert Table VI>}

Table VII explores the driving factors of acquirer M\&A gains through OLS regression models where the dependent variable equals cumulative abnormal returns over the event window $[-1,+1]$. We include the same explanatory variables as in the previous models and add a dummy capturing all stock payments as well as the interaction between this dummy variable and our proxies for acquirer information asymmetry and uncertainty. Results confirm 
the opposing impact of target information asymmetry and uncertainty. Target information asymmetry (as proxied by the second information asymmetry index as well as by lower analyst coverage, private status and a smaller size) is found to positively affect acquirer returns. For example, bidder returns in acquisitions of private targets are on average $3.7 \%$ higher compared to acquisitions of public targets, ceteris paribus. This confirms H2a and suggests that acquisitions of targets with high information asymmetry constitute a bargain relative to less opaque targets, due to the bidder's information advantage vis-à-vis other market participants. In line with this argument, the results in the previous section pointed out that rational bidders will try to avoid sharing the extra gains with target shareholders by offering fixed cash payments. In contrast, shareholders seem to react negatively when target uncertainty is high (as captured by both volatility measures and the composite index). We find that an increase of one basis point in implied (idiosyncratic) target volatility leads to $0.07 \%$ $(0.28 \%)$ lower bidder CARs. This also explains why acquirers do not tend to opt for fixed cash payments when the target's value is more uncertain.

Consistent with prior literature, we document a significantly negative impact of stock swaps on acquirer abnormal returns (e.g., Travlos, 1987; Huang and Walkling, 1987). As predicted (i.e., H3b), this negative impact is found to be stronger for acquirers characterized by higher information asymmetry and uncertainty. The impact of the interaction terms between our different proxies and the all-stock dummy is significantly negative. ${ }^{7}$ So, investors react more negatively on the announcement of stock swaps if acquirers are more informationally opaque and their values more uncertain. This finding indicates that investors recognize the opportunities for bidders to exploit temporary overvaluation. Our results support earlier conclusions of Moeller et al. (2007) who show that acquirer abnormal returns are negatively affected by information asymmetry and diversity-of-opinion proxies for stock

\footnotetext{
${ }^{7}$ Except for the interaction with analyst forecast error and dispersion.
} 
but not for cash offers. Concerning the control variables, we notice that tender offers result in higher acquirer abnormal returns, while cash ratios of both firms have a significantly negative impact.

\section{<Insert Table VII>}

\section{Division of gains}

We investigate the division of gains between the combining firms in two ways. First, following Ahern (2012) and Bauguess et al. (2009), we use the difference in dollar gains between bidder and target divided by the sum of the bidder's and target's pre-M\&A market value of equity. Dollar gains are calculated by multiplying bidder and target abnormal returns with their respective market capitalization at the end of the estimation window (i.e, 50 days before the announcement day). As argued by Ahern (2012), this measure represents the relative gain of the acquirer versus the target for each dollar of total market value. The average acquirer relative gain equals $-4.31 \%$ over the window $[-1,+1]$, suggesting that acquiring shareholders on average receive a lower part of the total gains than target shareholders, with the difference equalling $4.31 \%$ of the combined market value (see Panel B of Table VI). Moreover, only $28.17 \%$ of all transactions result in a positive relative acquirer return. Similar conclusions can be drawn for the other event windows $[-10,+10],[-5,+5],[-1,0]$ and $[0]$. Second, we measure the percentage of total dollar gains accruing to acquirer shareholders. Although the interpretation of this measure is more straightforward, results would be misleading if dollar returns are negative for either or both firms. Therefore, we perform this robustness check for the subsample where both firms realize positive CARs. This is the case for 661 out of 1725 deals. For this specific subsample, we observe that acquirer shareholders obtain $58.25 \%$ of the total value created through the M\&A in the window $[-1,+1]$. So, targets 
typically realize $41.75 \%$ of total dollar gains in the subsample where target and bidder realize positive CARs. The fraction of acquirer gains equals $62.87 \%, 61.87 \%, 60.11 \%$ and $60.32 \%$ for the event windows $[-10,+10],[-5,+5],[-1,0]$ and $[0]$, respectively. These figures are in line with the findings of Ahern (2012).

Table VIII reports OLS regressions studying the determinants of both the acquirer relative returns (Panel A) and the fraction of total returns accruing to acquirer shareholders (Panel B). We include the same proxies for information asymmetry and uncertainty, except for the private target dummy as the division of gains cannot be measured in case of private target acquisitions. The results support the notion that information availability influences the negotiation power of the combining entities in M\&A transactions. We notice that acquirers obtain a larger share of the total M\&A gains if the value of the target is less visible for outside investors, confirming the bargaining power hypothesis $(\mathrm{H} 2 \mathrm{c})$. High target information asymmetry allows the bidders to gain an information advantage in the M\&A process that can be exploited in price negotiations. In addition, acquirer asymmetric information is found to have a significantly negative impact in both panels. So, bidders earn the highest fraction of gains if targets are characterized by high information asymmetry while their own value is clearer for outside investors.

\section{$<$ Insert Table VIII >}

\section{Robustness checks}

We perform additional tests to assess the robustness of our findings. First, to distinguish between effects of information asymmetry/uncertainty and relative scarcity, we follow Ahern (2012) by adding industry concentration of both target and acquirer as additional control variables in our models. We rely on eight-firm concentration ratios as reported by the US 
Census Bureau to measure industry concentration. ${ }^{8}$ Second, Faccio and Masulis (2005) and Martynova and Renneboog (2009) argue that a potential change in control could discourage controlling shareholders of acquiring firms from paying through stock swaps. Therefore, we control for the ownership stake of the largest target's and acquirer's shareholder (gathered through Thomson Institutional Ownership Database). As industry and ownership concentration are only available for 1266 out of 1725 transactions, we do not include these variables in the main models but these results can be obtained from the authors upon request. Neither the target's and acquirer's industry concentration nor their largest shareholder stake play a significant role in determining the method of payment or the wealth effects. More importantly, prior conclusions on the impact of target and acquirer information asymmetry and uncertainty remain valid.

Next, we also use alternative abnormal return calculations. We consider longer event windows $([-5,+5]$ and $[-10,+10])$ and apply alternative techniques to calculate expected returns. We use the Fama and French (1993) three-factor model, for which the factors (i.e., market excess returns, small-minus-big market capitalization factor, and the high-minus-low book equity/market equity factor) are downloaded from Kenneth French's website. We also estimate a four-factor model including Carhart's (1997) momentum returns. Lastly, we compute industry adjusted returns as the difference between the actual returns and the industry raw return (see, for example, Kolari and Pynnönen, 2010). We use the 48 value-weighted Fama-French industry portfolios (Fama and French, 1997) to determine industry returns. The resulting average cumulative abnormal returns are found to be comparable across the different methodologies. Over the three-day event window surrounding the announcement, we observe a significant cumulative abnormal return of $-1.68 \%$ (24.81\%) for acquiring (target) firm's shareholders when using the market model, while this amounts to $-1.44 \%$ (24.98\%) for the

\footnotetext{
${ }^{8}$ We use figures from the 2002 US Census Bureau report, similar to what we did for industry value added.
} 
three-factor model, $-1.45 \%(24.97 \%)$ for the four-factor model and $-1.60 \%(24.71 \%)$ when using industry-adjusted returns. The results of the multivariate regressions (not reported) show that our findings are robust to these alternative specifications.

Finally, we also recognize that the endogenous nature of one of our asymmetric information proxies, namely the extent of analyst coverage, could potentially induce a selfselection bias in our models. This selection problem might result from financial analysts preferring to cover certain types of firms. These observable as well as latent firm characteristics could also impact the value that is being created in M\&A transactions. We control for such a potential bias using the approach of Chang et al. (2006) and Doukas et al. (2005, 2008), who use multiple instrumental variables in a two-step regression model. In particular, we focus on median industry coverage and S\&P 500 inclusion as instruments for analyst coverage. Higher analyst coverage is expected in industries that are typically better covered by analysts and for firms that are included in the S\&P500, while no specific relation with M\&A properties is anticipated. ${ }^{9}$ The results of these two-stage instrumental variable probit and least-squares regressions are presented in Appendix C. The first-stage regressions show that $\mathrm{S} \& \mathrm{P}$ inclusion is significant in explaining target and acquirer analyst coverage, while relative acquirer analyst coverage is also found to be positively related to the median analyst coverage in the industry. We also notice that the null hypothesis of exogeneity can only be rejected for the two-stage regression of acquirer relative returns (5\% level). While the impact of the instrumented relative acquirer analyst coverage and the interaction with the stock payment dummy in the second-stage regression support our earlier conclusions $(\mathrm{H} 3)$,

\footnotetext{
${ }^{9} \mathrm{Yu}(2008)$ proposes a two-stage least squares (2SLS) regression with expected coverage based upon changes in the size of brokerage houses, measured by their numbers of employees, as instrumental variable. The size of a brokerage house typically depends upon changes in its own revenue and is unlikely to be related to the M\&A properties of a particular firms that it covers. We also followed Yu's (2008) procedure with 1993 as our benchmark year and obtained similar findings. The disadvantage of the methodology is that firms need to be covered in the benchmark year in order to be able to calculate the expected coverage. We are left with only 226 observations of which we have both target and acquirer expected coverage. Given this relatively low number of observations, we do not report these regression models in the paper, but they can be obtained from the authors upon request.
} 
the coefficient of relative target analyst coverage is not found to be significant (although borderline with a $p$-value of 0.117 in the two-stage probit regression). ${ }^{10,11}$

\section{E. Economic drivers behind hypotheses}

We explicitly test the assumptions made in the development of some of our hypotheses. H2 relies on the notion that target information asymmetry negatively affects its bargaining strength in M\&A transactions. We consider three proxies for target negotiation power that have been used in prior literature. First, if multiple bidders are interested, targets are expected to have a stronger bargaining position as rivalry amongst the bidding firms is likely to drive up offer prices and lead to better deal terms (Eckbo, 2009). We analyse a dummy variable capturing whether at least one rival offer has been made, as well as the actual number of rival bidders. Second, we assume acquirers to have a stronger bargaining position if they succeed in negotiating an agreement where targets have to pay a premium when they would later withdraw their consent (Officer, 2003), especially if they achieve this without having to accept upon a similar acquirer-payable termination fee. Third, Heitzman (2011) suggests an intuitive way of capturing target bargaining power. He argues that acquisitions initiated by acquiring firms signal a stronger negotiation position for target shareholders compared to deals in which targets put themselves up for sale. Following Heitzman (2011) and Masulis and Simsir (2015), we carefully analyse all actions taken by both parties during the M\&A process through the background documents that are filed with the Securities and Exchange Commission (SEC). We performed this search for the 200 largest deals in our sample and were able to identify the

\footnotetext{
${ }^{10}$ Concerning the interaction term, we follow Wooldridge (2002) who argues that the most natural choice of instrument for this additional potential endogenous variable is the interaction between the instruments for relative acquirer coverage and the stock payment dummy (see also Bun and Harrison, 2014).

${ }^{11}$ We test whether the instruments are uncorrelated with the error term through Sargan's Chi ${ }^{2}$ test statistic. As it is found to be insignificant, we can conclude that our instruments are not invalid.
} 
initiating party in 117 transactions, of which $19.66 \%$ were target initiated. The correlation coefficients presented in table IX confirm that our indices capturing target information asymmetry are negatively related to target's bargaining power. Although not all proxies are significantly related to each of the measures for bargaining power, all individual asymmetric information proxies are significantly associated with at least one of our bargaining constructs. Smaller targets and targets with lower analyst coverage are less likely to receive offers by multiple bidders. Acquisitions of targets characterised by higher analyst forecast error and dispersion are more likely to be target initiated. Lower coverage of targets in the media is associated with the existence of target-only termination fees. The index capturing all proxies of asymmetric information (= index 2$)$ demonstrates that more opaque targets are less likely to incite rival offers and are more inclined to accept termination fees without a similar concession of bidding companies. In general, given all of these associations, we are confident that our proxies for information asymmetry are correlated with the bargaining power of target versus bidder in the M\&A process. ${ }^{12}$

\section{$<$ Insert Table IX>}

Second, H3 builds upon the argument that overvalued bidders characterized by high information asymmetry/uncertainty purchase less overvalued targets. We study whether our empirical proxies are indeed related to relative acquirer versus target misvaluation by following the procedure developed by Rhodes-Kropf et al. (2005). They compare a firm's equity value in the market with its true value, estimated through a linear function of accounting information and a vector of conditional accounting multiples. The proposed model links market value of equity to book value of equity, net income and leverage as follows:

\footnotetext{
12 The only surprising and conflicting finding is that lower analyst coverage is found to be associated with a reduced likelihood of target-only termination fee.
} 
$\mathrm{LN}(\mathrm{MV})_{i t}=\alpha_{0 j t}+\alpha_{1 j t} \mathrm{LN}(\mathrm{BV})_{\mathrm{it}}+\alpha_{2 j t} \mathrm{LN}(\mathrm{NI})_{i t}+\alpha_{3 j t} I_{(<0)} \mathrm{LN}(\mathrm{NI})_{\mathrm{it}}+\alpha_{4 j t} \mathrm{LEV}_{\mathrm{it}}+\varepsilon_{\mathrm{it}}$

with $\mathrm{LN}(\mathrm{MV})_{i t}=$ Natural logarithm of market value of equity for firm $i$ in year $t$

$\mathrm{LN}(\mathrm{BV})_{i t}=$ Natural logarithm of book value of equity for firm $i$ in year $t$

$\mathrm{LN}(\mathrm{NI})_{i t}=$ Natural logarithm of absolute value of net income for firm $i$ in year $t$

$I_{(<0)} \mathrm{LN}(\mathrm{NI})_{i t}=$ An indicator variable for negative net income interacted with the natural logarithm of absolute value of net income for firm $i$ in year $t$

$\mathrm{LEV}_{i t}=$ Leverage ratio for firm $i$ in year $t$

The indicator function $I_{(<0)} \mathrm{LN}(\mathrm{NI})_{i t}$ allows firms with negative net income to enter the regression even though it is estimated in logarithms.

This cross-sectional model is estimated for each industry $j$ and each year $t$ separately.

Following Rhodes-Kropf et al. (2005), we group all Compustat firms in 12 Fama and French industries. The extent of firm-specific misvaluation is proxied by the firm's deviation from the valuation implied by the sector valuation multiples $\alpha_{k j t}$ (with $\left.k=0, \ldots, 4\right)$, calculated as in Eq. (1). Finally, we look at the difference between acquirer and target misvaluation (scaled by size) in order to capture relative misvaluation of acquirer versus target. The correlations in Table IX demonstrate that our indices of acquirer information asymmetry (second asymmetric information index, inverse of acquirer size and inverse of media coverage) and all uncertainty proxies are positively associated with the extent of relative acquirer versus target misvaluation.

\section{Conclusions}

A double-sided problem of asymmetric information and uncertainty arises in M\&A transactions because the values of both target and acquirer are uncertain and information might be unevenly distributed. In this paper, we explore the consequences of limited 
information availability and uncertainty and the strategic exploitation of information advantages by investigating the payment consideration as well as the wealth effects in a sample of 1,725 acquisition announcements of public targets and 1,810 announcements of private targets during 1994-2011.

We illustrate differing effects for target information asymmetry and uncertainty on the type of payment offered to target shareholders. In line with the risk-sharing hypothesis, acquisitions of target firms characterised by higher uncertainty are more likely to be settled with stock offers. Higher target information asymmetry, on the other hand, increases the likelihood of cash payments. We argue that rational bidders have incentives to offer cash in acquisitions of more informationally opaque targets because they expect to realize higher gains and avoid sharing these gains with target shareholders. Our empirical results confirm that bidders realise higher announcement returns and earn a larger fraction of total gains if targets are affected by higher information asymmetry. These higher gains stem from a stronger bargaining power of the bidders in this type of transactions. We also provide evidence of a positive association between our measures of target information asymmetry and several proxies for bidder's negotiation power in M\&A transactions.

Our results also show that the difficulty of estimating the buyer's real value incites market-timing behaviour through a higher incidence of stock swaps. The extent of information asymmetry and uncertainty on the acquirer's value is found to be positively related to the relative misvaluation of the acquirer versus the target firm. Accordingly, the typically more negative stock price reaction upon the announcement of stock offers is found to be stronger for more opaque bidders.

Finally, we show that these forces do not offset each other but instead act together, leading to a fraction of $62.90 \%$ cash offers if target information asymmetry ranks in the top tercile while that of bidder lies in the bottom tercile, compared to $31.43 \%$ in the reverse 
situation. In addition, we find that only $16.47 \%$ use cash if both target and acquirer are part of the top tercile of uncertainty.

Our findings may have important implications for academia as well as practice. Our results add to the available literature on information constraints and illustrate opportunities for the strategic use of superior information. Also, we provide additional insights in the antecedents of the payment consideration in M\&A transactions, showing that rational bidders take into account the expected value creation through the M\&A when they decide upon the type of payment. Furthermore, our results demonstrate the importance of differentiating between asymmetric information and symmetric uncertainty that affects all market participants. Finally, investigating these issues in other geographic settings and, especially in cross-border M\&As where the impact of information asymmetry is likely to be higher, may constitute interesting avenues for future research. 


\section{References}

Ahern, K.R., 2012, "Bargaining power and industry dependence in mergers," Journal of Financial Economics 103, 530-550.

Ahern, K.R., and D. Sosyura, 2014, "Who Writes the News? Corporate Press Releases during Merger Negotiations", Journal of Finance 69, 241-291.

Baker, M., and J. Wurgler, 2002, "Market timing and capital structure," Journal of Finance $57,1-32$.

Baker, M., and J. Wurgler, 2007, "Investor Sentiment in the Stock Market," Journal of Economic Perspectives 21, 129-151.

Barber, B. and T. Odean, 2008. "All that glitters: the effect of attention and news on the buying behaviour of individual and institutional investors," Review of Financial Studies 21, 785818.

Bargeron, L.L., K. Lehn, S.B. Moeller, and F.P. Schlingemann, 2014, "Disagreement and the informativeness of stock returns: the case of acquisition announcements," Journal of Corporate Finance 25, 155-172.

Barron, O., O. Kim, S. Lim, and D. Stevens, 1998, "Using analysts' forecasts to measure properties of analysts' information environment," Accounting review 73, 421-433.

Bauguess, S.W., S.B. Moeller, F.P. Schlingemann, and C.J. Zutter, 2009, “Ownership structure and target returns," Journal of Corporate Finance 15, 48-65.

Bowen, R.M., X. Chen, and Q. Cheng, 2008, “Analyst coverage and the cost of raising equity capital: evidence from underpricing of seasoned equity offerings," Contemporary Accounting Research 25, 657-699.

Brennan, M.J., N. Jegadeesh, and B. Swaminatham, 1993, "Investment analysis and the adjustment of stock prices to common information," Review of Financial Studies 6, 799824.

Brennan, M.J., and A. Subrahmanyan, 1995, "Investment analysis and price formation in securities markets," Journal of Financial Economics 38, 361-381.

Brown D.T., and M.D. Ryngaert, 1991, "The Mode of Acquisition in Takeovers: Taxes and Asymmetric Information,” Journal of Finance 46, 653-669.

Bruner, R.F., 2004, Applied mergers and acquisitions, New York, NY, John Wiley and Sons.

Bun, M.J.G., and T.D. Harrison, 2014, "OLS and IV estimation of regression models including endogenous interaction terms," School of Economics Working Paper Series, LeBow College of Business, Drexel University. 
Capron, L., and J. Shen, 2007, “Acquisitions of private versus public firms: private information, target selection, and acquirer returns," Strategic Management Journal 28, 891-911.

Carhart, M.M., 1997, "On the persistence in mutual fund performance”, Journal of Finance $52,57-82$.

Chang, S., 1998, "Takeovers of privately held targets, method of payment, and bidder returns," Journal of Finance 52, 773-784.

Chang, X., S. Dasgupta, and G. Hilary, 2006, "Analyst coverage and financing decisions," Journal of Finance 61, 3009-3048.

Chatterjee, S., K. John, and A. Yan, 2012, "Takeovers and Divergence of Investor Opinion," Review of Financial Studies 25, 227-277.

Chemmanur, T.J., I. Paeglis, and K. Simonyan, 2009, "The medium of exchange in acquisitions: does the private information of both acquirer and target matter?" Journal of Corporate Finance 15, 523-542.

Chung, K.H., and H. Jo, 1996, “The impact of security analysts' monitoring and marketing functions on the market value of firms," Journal of Financial and Quantitative Analysis 31, 493-512.

Dodd, P., and J.B. Warner, 1983, "On corporate governance: A study of proxy contests," Journal of Financial Economics 11, 401-438.

Dong, M., D. Hirshleifer, S. Richardson, and S.H. Teoh, 2006, "Does investor misvaluation drive the takeover market," Journal of Finance 61, 725-762.

Doukas J.A., C. Kim, and C. Pantzalis, 2005, “The two faces of analyst coverage,” Financial Management 34, 99-125.

Doukas, J.A., C. Kim, and C. Pantzalis, 2008, "Do analysts influence corporate financing and investment?" Financial Management 37, 303-339.

Duchin, R., and B. Schmidt, 2013, "Riding the Merger Wave," Journal of Financial Economics 107, 69-88.

Eckbo, B.E., R.M. Giammarino, and R.L. Heinkel, 1990, "Asymmetric information and the medium of exchange in takeovers: theory and tests," Review of Financial Studies 3, 651675.

Eckbo, B.E., 2009, "Bidding strategies and takeover premiums: A review," Journal of Corporate Finance 15, 149-178.

Faccio, M., and R.W. Masulis, 2005, "The choice of payment method in European mergers and acquisitions," Journal of Finance 60, 1345-1388. 
Fama, E.F., and K.R. French, 1993, “The cross-section of expected stock returns”, Journal of Finance 47, 427-465.

Fama, E.F., and K.R. French, 1997, "Industry costs of equity", Journal of Financial Economics 43, 153-193.

Fang, L.H., and Peress, J., 2009, "Media coverage and the cross-section of stock returns," Journal of Finance 64, 2023-2052.

Fishman, M., 1989, "Preemptive bidding and the role of the medium of exchange in acquisitions," Journal of Finance 44, 41-57.

Fuller, K., J. Netter, and M. Stegemoller, 2002, "What do returns to acquiring firms tell us? Evidence from firms that make many acquisitions," Journal of Finance 57, 1763-1794.

Graham, J.R., and C.R. Harvey, 2001, "The theory and practice of corporate finance: Evidence from the field," Journal of Financial Economics 60, 187-243.

Hansen, R.G., 1987, "A theory for the choice of exchange medium in mergers and acquisitions," Journal of Business 60, 75-95.

Harford, J., S. Klasa, and N. Walcott, 2009, "Do firms have leverage targets? Evidence from acquisitions," Journal of Financial Economics 93, 1-14.

Hartzell, J.C., E. Ofek and D. Yermack, 2004, "What's in it for me? CEOs whose firms are acquired," Review of Financial Studies 17, 37-61.

Heitzman, S., 2011, "Equity grants to target CEOs during deal negotiations," Journal of Financial Economics 102, 251-271

Huang, Y., and R.A. Walkling, 1987, "Target abnormal returns associated with acquisition announcements: Payment, acquisition form, and managerial resistance," Journal of Financial Economics 19, 329-349.

Irvine, P., 2003, "The incremental impact of analyst initiation of coverage," Journal of Corporate Finance 9, 431-451.

Kelly, B., and A. Ljungqvist, 2012, "Testing asymmetric-information asset pricing models," Review of Financial Studies 25, 1366-1413.

Kolari, J.W., and S. Pynnönen, 2010, "Event study testing with cross-sectional correlation of abnormal returns", Review of Financial Studies 23, 3996-4025.

Krishnaswami S., and V. Subramaniam, 1999, "Information asymmetry, valuation, and the corporate spin-off decision," Journal of Financial Economics 53, 73-112.

Lu, C.-W., T.-K. Chen, and H.-H. Liao, 2010, "Information uncertainty, information asymmetry and corporate bond yield spreads," Journal of Banking \& Finance 34, 22652279. 
Lin, B.J., C. Pantzalis, and J.C. Park, 2009, "Derivatives Use, Information Asymmetry and MNC Post-Acquisition Performance,” Financial Management 38, 631-661.

Loughran, T., and J. Ritter, 1995, “The new issues puzzle,” Journal of Finance 50, 23-51.

Loughran, T., and A. Vijh, 1997, "Do long-term shareholders benefit from corporate acquisitions?" Journal of Finance 52, 1765-1790.

Mantecon, T., 2008, "An analysis of the implications of uncertainty and agency problems on the wealth effects to acquirers of private firms," Journal of Banking and Finance 32, 892905.

Martin, K.J., 1996, "The Method of Payment in Corporate Acquisitions, Investment Opportunities, and Management Ownership,” Journal of Finance 51, 1227-1246.

Martynova, M., and L. Renneboog, 2009, "What determines the financing decision in corporate takeovers: Cost of Capital, Agency problems, or the means of payment?" Journal of Corporate Finance 15, 290-315.

Masulis, R.W., and S.A. Simsir, 2015, "Deal Initiation in Mergers and Acquisitions," ECGI - Finance Working Paper.

McSweeney, B., 2012, “Takeover Strategies, Competitive Bidding and Defence Tactics," in Faulkner, D., S. Teerikangas, and R. J.Joseph, Eds., Handbook of Mergers and Acquisitions, Oxford, Oxford University Press.

Moeller, S.B., F.P. Schlingemann, and R.M. Stulz, 2007, "How do diversity of opinion and information asymmetry affect acquirer returns?" Review of Financial Studies 20, 20472078.

Mola, S., P. Raghavendra R., and A. Khorana, 2013, "Is There Life after the Complete Loss of Analyst Coverage?" The Accounting Review 88, 667-705.

Myers, S.C., and N.S. Majluf, 1984, "Corporate financing and investment decisions when firms have information that investors do not have," Journal of Financial Economics 13, 187-221.

Officer M.S., 2003, "Termination fees in mergers and acquisitions," Journal of Financial Economics 69, 431-467.

Officer M.S., A.B Poulsen, and M. Stegemoller, 2009, “Target-firm information asymmetry and acquirer returns," Review of Finance 13, 467-493.

Raman, K., L. Shivakumar, and A. Tamayo, 2013,” Target's earnings quality and bidders' takeover decisions," Review of Accounting Studies 18, 1050-1087. 
Reuer, J.J., O. Shenkar, and R. Ragozzino, 2004, "Mitigating risk in international mergers and acquisitions: the role of contingent payouts," Journal of International Business Studies $35,19-32$.

Rhodes-Kropf, M., and S. Viswanathan, 2004, "Market valuation and merger waves," Journal of Finance 59, 2685-2718.

Rhodes-Kropf, M., D.T. Robinson, and S. Viswanathan, 2005, "Valuation waves and merger activity: the empirical evidence," Journal of Financial Economics 77, 561-603.

Ritter, J., 1991, “The long-run performance of initial public offerings," Journal of Finance 46, 3-27.

Shleifer, A., and R.W. Vishny, 2003, "Stock market driven acquisitions," Journal of Financial Economics 70, 295-311.

Tetlock, P.C., 2010, “Does public financial news resolve asymmetric information?" Review of Financial Studies 23, 3520-3557.

Travlos, N., 1987, “Corporate takeover bids, methods of payment, and bidding firm's stock returns," Journal of Finance 42, 943-964.

Wooldridge, J.M., 2002, Econometric analysis of cross-section and panel data, The MIT Press, Cambridge.

Yu, F., 2008, “Analyst Coverage and earnings management,” Journal of Financial Economics 88, 245-271.

Zhang, X.F., 2006, "Information Uncertainty and Stock Returns,” Journal of Finance 61, 105-136. 


\section{Table I: Overview proxies and hypotheses}

This table presents the proxies used for target and acquirer information asymmetry and uncertainty and their hypothesized effect on the likelihood of cash payments, acquirer CAR over the window $[-1,+1]$ and the acquirer gains relative to the target gains.

\begin{tabular}{|c|c|c|c|c|c|}
\hline & & \multirow{2}{*}{ PROXIES } & \multicolumn{3}{|c|}{ DEPENDENT VARIABLES } \\
\hline & & & $\begin{array}{l}\text { LIKELIHOOD } \\
\text { OF CASH }\end{array}$ & $\begin{array}{l}\text { ACQUIRER } \\
\text { CAR }\end{array}$ & $\begin{array}{l}\text { ACQUIRER } \\
\text { RELATIVE } \\
\text { GAINS }\end{array}$ \\
\hline \multirow[t]{2}{*}{ Target } & Information asymmetry & $\begin{array}{l}\text { Composite asymmetric information index } 1 \\
\text { Composite asymmetric information index } 2 \\
\text { Inverse of relative analyst coverage } \\
\text { Analyst forecast error } \\
\text { Analyst forecast dispersion } \\
\text { Inverse of relative media coverage } \\
\text { Private target dummy }\end{array}$ & $\begin{array}{l}-(\mathrm{H} 1) / \\
+(\mathrm{H} 2 \mathrm{a})\end{array}$ & $+(\mathrm{H} 2 \mathrm{~b})$ & $+(\mathrm{H} 2 \mathrm{c})$ \\
\hline & Uncertainty & $\begin{array}{l}\text { Composite uncertainty index } \\
\text { Implied volatility } \\
\text { Idiosyncratic volatility }\end{array}$ & $-(\mathrm{H} 1)$ & I & / \\
\hline \multirow{4}{*}{ Acquirer } & Information asymmetry & $\begin{array}{l}\text { Composite asymmetric information index } 1 \\
\text { Composite asymmetric information index } 2 \\
\text { Inverse of relative analyst coverage } \\
\text { Analyst forecast error } \\
\text { Analyst forecast dispersion } \\
\text { Inverse of relative media coverage } \\
\text { Private target dummy }\end{array}$ & $-(\mathrm{H} 3 \mathrm{a})$ & I & I \\
\hline & Uncertainty & $\begin{array}{l}\text { Composite uncertainty index } \\
\text { Implied volatility } \\
\text { Idiosyncratic volatility }\end{array}$ & $-(\mathrm{H} 3 \mathrm{a})$ & I & l \\
\hline & $\begin{array}{l}\text { Information asymmetry } \\
* \text { stock }\end{array}$ & $\begin{array}{l}\text { Composite asymmetric information index } 1 \text { *stock } \\
\text { Composite asymmetric information index } 2 * \text { stock } \\
\text { Inverse of relative analyst coverage*stock } \\
\text { Analyst forecast error*stock } \\
\text { Analyst forecast dispersion*stock } \\
\text { Inverse of relative media coverage*stock } \\
\text { Private target dummy*stock }\end{array}$ & I & $-(\mathrm{H} 3 \mathrm{~b})$ & l \\
\hline & $\begin{array}{l}\text { Uncertainty* } \\
\text { stock }\end{array}$ & $\begin{array}{l}\text { Composite uncertainty index*stock } \\
\text { Implied volatility*stock } \\
\text { Idiosyncratic volatility*stock }\end{array}$ & I & $-(\mathrm{H} 3 \mathrm{~b})$ & I \\
\hline
\end{tabular}




\section{Table II: Descriptive statistics}

This table reports the deal characteristics for the M\&As included in our sample, year by year. We separate between acquisitions of public and private targets. We observe the yearly number of announced and completed deals, the amount of tender offers, hostile offers, offers where a rival bidder is identified, the industry-relatedness of the deal (according to 4-digit SIC level) and the method of payment (stock, mixed or cash).

\begin{tabular}{|c|c|c|c|c|c|c|c|c|c|}
\hline & ANNOUNCED & COMPLETED & $\begin{array}{c}\text { TENDER } \\
\text { OFFER } \\
\end{array}$ & $\begin{array}{c}\text { HOSTILE } \\
\text { OFFER }\end{array}$ & $\begin{array}{l}\text { RIVAL } \\
\text { OFFER } \\
\end{array}$ & RELATED & STOCK & MIXED & CASH \\
\hline \multicolumn{10}{|c|}{ Public - Public Transactions: } \\
\hline 1994 & 70 & 51 & 17 & 7 & 9 & 34 & 39 & 8 & 23 \\
\hline 1995 & 108 & 89 & 25 & 9 & 12 & 41 & 60 & 16 & 32 \\
\hline 1996 & 106 & 89 & 25 & 5 & 11 & 38 & 58 & 16 & 32 \\
\hline 1997 & 141 & 121 & 38 & 9 & 11 & 49 & 69 & 28 & 44 \\
\hline 1998 & 163 & 149 & 36 & 4 & 9 & 64 & 69 & 42 & 52 \\
\hline 1999 & 191 & 160 & 46 & 17 & 14 & 65 & 84 & 39 & 68 \\
\hline 2000 & 159 & 141 & 41 & 9 & 9 & 58 & 69 & 37 & 53 \\
\hline 2001 & 117 & 100 & 29 & 8 & 12 & 49 & 37 & 38 & 42 \\
\hline 2002 & 70 & 67 & 20 & 3 & 3 & 25 & 20 & 17 & 33 \\
\hline 2003 & 65 & 57 & 18 & 7 & 4 & 36 & 15 & 22 & 28 \\
\hline 2004 & 63 & 57 & 8 & 5 & 5 & 27 & 12 & 20 & 31 \\
\hline 2005 & 83 & 75 & 8 & 8 & 10 & 33 & 13 & 25 & 45 \\
\hline 2006 & 81 & 68 & 9 & 8 & 12 & 27 & 9 & 15 & 57 \\
\hline 2007 & 69 & 62 & 17 & 4 & 4 & 22 & 3 & 15 & 51 \\
\hline 2008 & 67 & 46 & 21 & 15 & 6 & 33 & 6 & 14 & 47 \\
\hline 2009 & 61 & 55 & 24 & 7 & 7 & 25 & 8 & 25 & 28 \\
\hline 2010 & 70 & 60 & 19 & 6 & 6 & 31 & 9 & 16 & 45 \\
\hline 2011 & 41 & 25 & 7 & 8 & 7 & 17 & 7 & 15 & 19 \\
\hline All & $\begin{array}{c}1725 \\
(100.00 \%)\end{array}$ & $\begin{array}{c}1472 \\
(85.33 \%)\end{array}$ & $\begin{array}{c}\mathbf{4 0 8} \\
(23.65 \%)\end{array}$ & $\begin{array}{c}139 \\
(8.06 \%)\end{array}$ & $\begin{array}{c}151 \\
(8.75 \%)\end{array}$ & $\begin{array}{c}\mathbf{6 7 4} \\
(39.07 \%)\end{array}$ & $\begin{array}{c}\mathbf{5 8 7} \\
(34.03 \%)\end{array}$ & $\begin{array}{c}\mathbf{4 0 8} \\
(23.65 \%)\end{array}$ & $\begin{array}{c}\mathbf{7 3 0} \\
(42.32 \%)\end{array}$ \\
\hline
\end{tabular}

Public - Private Transactions:

\begin{tabular}{|c|c|c|c|c|c|c|c|c|c|}
\hline 1994 & 109 & 100 & 1 & 0 & 0 & 37 & 62 & 29 & 18 \\
\hline 1997 & 167 & 149 & 0 & 0 & 3 & 57 & 112 & 29 & 26 \\
\hline 1998 & 165 & 161 & 0 & 0 & 0 & 46 & 93 & 51 & 21 \\
\hline 2000 & 217 & 208 & 0 & 0 & 0 & 64 & 145 & 50 & 22 \\
\hline 2001 & 65 & 63 & 0 & 0 & 0 & 19 & 23 & 24 & 18 \\
\hline 2002 & 57 & 56 & 0 & 0 & 0 & 23 & 16 & 18 & 23 \\
\hline 2005 & 88 & 81 & 0 & 0 & 1 & 34 & 9 & 19 & 60 \\
\hline 2006 & 78 & 77 & 0 & 0 & 0 & 31 & 11 & 26 & 41 \\
\hline 2007 & 93 & 88 & 0 & 0 & 0 & 40 & 9 & 28 & 56 \\
\hline 2008 & 56 & 56 & 0 & 0 & 0 & 25 & 4 & 22 & 30 \\
\hline 2009 & 43 & 42 & 0 & 0 & 0 & 18 & 9 & 11 & 23 \\
\hline 2010 & 34 & 33 & 1 & 0 & 0 & 10 & 2 & 7 & 25 \\
\hline
\end{tabular}




\section{Table III: Proxies for information asymmetry and firm characteristics}

This table reports summary statistics on the following target and acquirer characteristics in the year before the M\&A: analyst coverage (=number of financial analysts), analyst forecast dispersion (=standard deviation EPS/stock price), analyst forecast error (= absolute value of the difference between median EPS estimate and actual value/stock price), media coverage (=number of Factiva articles in pre-M\&A year), implied volatility, total assets, market capitalization, market-to-book ratio of equity (M/B), cash ratio (=cash and cash equivalents/total assets), debt ratio (=total debt/total assets), profitability (=EBITDA/total assets) and $\mathrm{R} \& \mathrm{D}(=\mathrm{R} \& \mathrm{D}$ expenses/total assets)

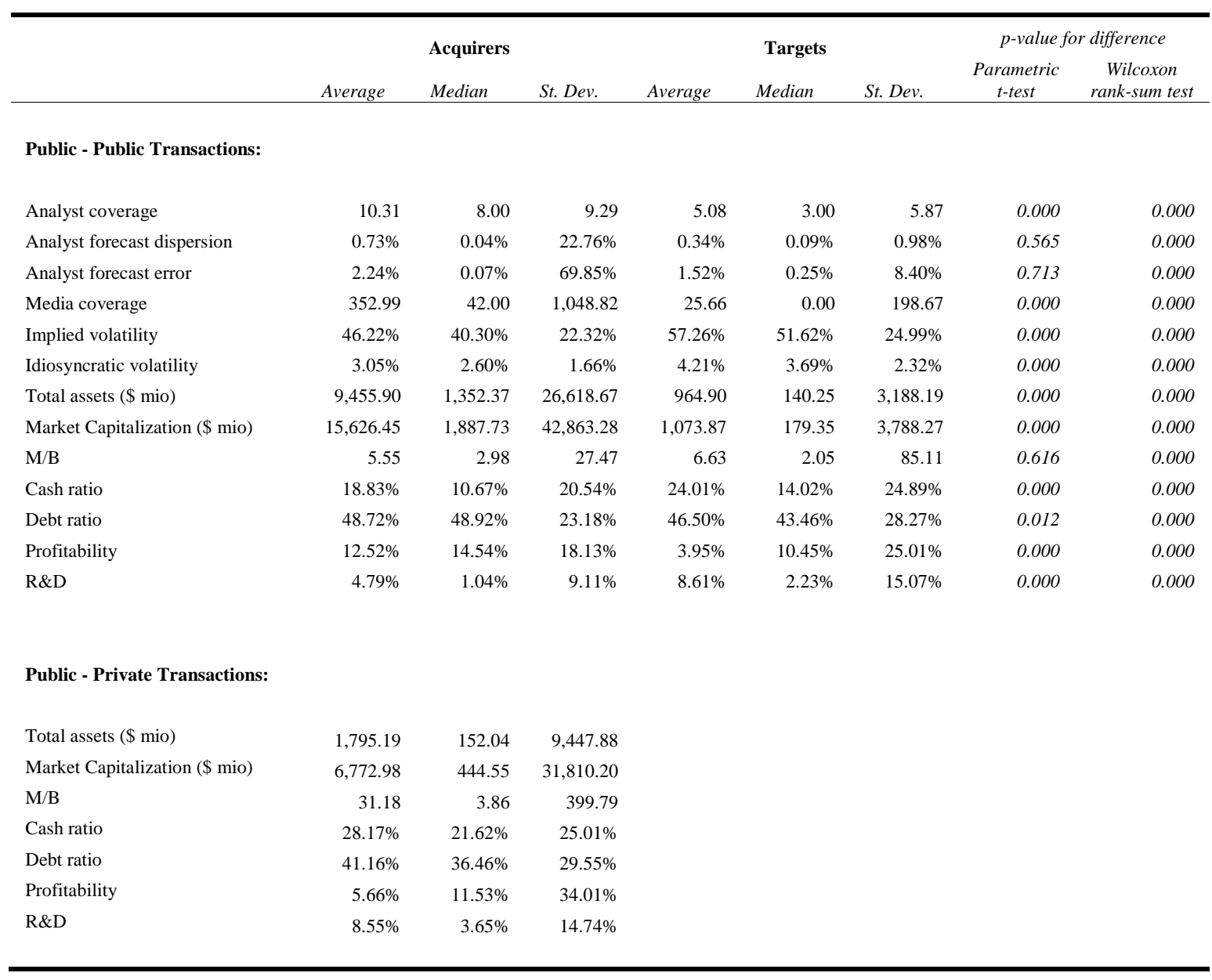


Table IV: Determinants of the likelihood of cash payments

This table reports the results of binary probit regressions where the dependent variable equals one in case of a cash offer. The following proxies for target and acquirer information asymmetry are considered as explanatory variables in the model: Composite asymmetric information index 1 (=composite index including the inverse of normalized relative analyst coverage, normalized analyst forecast dispersion, normalized analyst forecast error and the inverse of normalized relative media coverage), Composite asymmetric information index 2 (=composite index including the inverse of normalized relative analyst coverage, normalized analyst forecast dispersion, normalized analyst forecast error, the inverse of normalized relative media coverage and normalized firm size), the inverse of relative analyst coverage (=number of financial analysts/firm size), analyst forecast error (=absolute value of the difference between median EPS estimate and actual value/stock price), analyst forecast dispersion (=standard deviation EPS/stock price), the inverse of relative media coverage (=number of Factiva articles in pre-M\&A year/firm size) and a dummy capturing private targets. The degree of uncertainty is captured by implied and idiosyncratic stock return volatility as well as a composite index of both normalized volatility measures. The control variables include the natural logarithm of firm size, the relative size of target versus bidder, dummies capturing respectively whether it is a tender, an hostile or an inger a

\begin{tabular}{|c|c|c|c|c|c|c|c|c|c|c|c|c|c|c|c|c|c|c|c|c|}
\hline \multirow[b]{3}{*}{ Constant } & \multicolumn{14}{|c|}{ Proxy for information asymmetry } & \multicolumn{6}{|c|}{ Proxy for uncertainty } \\
\hline & \multicolumn{2}{|c|}{$\begin{array}{c}\text { Composite } \\
\text { asymmetric } \\
\text { information } \\
\text { index } 1 \\
\end{array}$} & \multicolumn{2}{|c|}{$\begin{array}{c}\text { Composite } \\
\text { asymmetric } \\
\text { information } \\
\text { index } 2 \\
\end{array}$} & \multicolumn{2}{|c|}{$\begin{array}{l}\text { Inverse of } \\
\text { relative analyst } \\
\text { coverage }\end{array}$} & \multicolumn{2}{|c|}{$\begin{array}{c}\text { Analyst } \\
\text { forecast error }\end{array}$} & \multicolumn{2}{|c|}{$\begin{array}{l}\text { Analyst forecast } \\
\text { dispersion }\end{array}$} & \multicolumn{2}{|c|}{$\begin{array}{l}\text { Inverse of } \\
\text { relative media } \\
\text { coverage }\end{array}$} & \multicolumn{2}{|c|}{$\begin{array}{c}\text { Private target } \\
\text { dummy }\end{array}$} & \multicolumn{2}{|c|}{$\begin{array}{c}\text { Composite } \\
\text { uncertainty } \\
\text { index }\end{array}$} & \multicolumn{2}{|c|}{$\begin{array}{l}\text { Implied } \\
\text { volatility }\end{array}$} & \multicolumn{2}{|c|}{$\begin{array}{l}\text { Idiosyncratic } \\
\text { volatility }\end{array}$} \\
\hline & $\begin{array}{l}-0.956 \\
(0.099)\end{array}$ & * & $\begin{array}{l}-0.059 \\
(0.893)\end{array}$ & & $\begin{array}{l}-1.085 \\
(0.003)\end{array}$ & $* * * *$ & $\begin{array}{l}-0.782 \\
(0.098)\end{array}$ & * & $\begin{array}{l}-0.188 \\
(0.717)\end{array}$ & & $\begin{array}{l}-0.742 \\
(0.032)\end{array}$ & $* *$ & $\begin{array}{l}-1.192 \\
(0.000)\end{array}$ & ***** & $\begin{array}{l}-1.607 \\
(0.124)\end{array}$ & & $\begin{array}{r}1.373 \\
(0.264)\end{array}$ & & $\begin{array}{r}0.036 \\
(0.921)\end{array}$ & \\
\hline Target information asymmetry & $\begin{array}{r}0.356 \\
(0.009)\end{array}$ & $* * *$ & $\begin{array}{r}0.544 \\
(0.001)\end{array}$ & $* * *$ & $\begin{array}{r}0.180 \\
(0.004)\end{array}$ & $* * *$ & $\begin{array}{r}1.989 \\
(0.093)\end{array}$ & $*$ & $\begin{array}{l}11.359 \\
(0.056)\end{array}$ & $*$ & $\begin{array}{r}0.001 \\
(0.155)\end{array}$ & & $\begin{array}{r}0.428 \\
(0.000)\end{array}$ & $* * *$ & & & & & & \\
\hline Target uncertainty & & & & & & & & & & & & & & & $\begin{array}{r}-0.585 \\
(0.025)\end{array}$ & $* *$ & $\begin{array}{l}-1.934 \\
(0.021)\end{array}$ & ** & $\begin{array}{l}-1.864 \\
(0.551)\end{array}$ & \\
\hline Target size & $\begin{array}{r}-0.319 \\
(0.000)\end{array}$ & $* * *$ & & & $\begin{array}{r}-0.305 \\
(0.000)\end{array}$ & $* * *$ & $\begin{array}{r}-0.368 \\
(0.000)\end{array}$ & $* * *$ & $\begin{array}{l}-0.352 \\
(0.000)\end{array}$ & $* * *$ & $\begin{array}{r}-0.352 \\
(0.000)\end{array}$ & $* * *$ & & & $\begin{array}{l}-0.657 \\
(0.000)\end{array}$ & $* * *$ & $\begin{array}{l}-0.667 \\
(0.000)\end{array}$ & $* * *$ & $\begin{array}{l}-0.367 \\
(0.000)\end{array}$ & *** \\
\hline Acquirer information asymmetry & $\begin{array}{r}0.152 \\
(0.378)\end{array}$ & & $\begin{array}{c}-0.368 \\
(0.066)\end{array}$ & * & $\begin{array}{r}0.079 \\
(0.101)\end{array}$ & & $\begin{array}{r}6.229 \\
(0.004)\end{array}$ & $* * *$ & $\begin{array}{r}-134.442 \\
(0.018)\end{array}$ & ** & $\begin{array}{l}-0.000 \\
(0.810)\end{array}$ & & & & & & & & & \\
\hline Acquirer uncertainty & & & & & & & & & & & & & & & $\begin{array}{r}-0.895 \\
(0.001)\end{array}$ & $* * *$ & $\begin{array}{r}-3.740 \\
(0.001)\end{array}$ & $* * *$ & $\begin{array}{r}-18.559 \\
(0.000)\end{array}$ & *** \\
\hline Acquirer size & $\begin{array}{r}0.341 \\
(0.000)\end{array}$ & $* * *$ & & & $\begin{array}{r}0.317 \\
(0.000)\end{array}$ & $* * *$ & $\begin{array}{r}0.299 \\
(0.000)\end{array}$ & $* * *$ & $\begin{array}{r}0.290 \\
(0.000)\end{array}$ & $* * *$ & $\begin{array}{r}0.285 \\
(0.000)\end{array}$ & $* * *$ & $\begin{array}{r}0.099 \\
(0.000)\end{array}$ & $* * *$ & $\begin{array}{r}0.447 \\
(0.000)\end{array}$ & $* * *$ & $\begin{array}{r}0.439 \\
(0.000)\end{array}$ & $* * *$ & $\begin{array}{r}0.233 \\
(0.000)\end{array}$ & *** \\
\hline Target size/Acquirer size & $\begin{array}{r}-0.164 \\
(0.408)\end{array}$ & & $\begin{array}{l}-0.785 \\
(0.000)\end{array}$ & $* * *$ & $\begin{array}{r}0.114 \\
(0.000)\end{array}$ & $* * *$ & $\begin{array}{r}-0.144 \\
(0.451)\end{array}$ & & $\begin{array}{r}-0.182 \\
(0.359)\end{array}$ & & $\begin{array}{r}0.108 \\
(0.000)\end{array}$ & $* * *$ & & & $\begin{array}{l}-0.293 \\
(0.319)\end{array}$ & & $\begin{array}{l}-0.285 \\
(0.323)\end{array}$ & & $\begin{array}{r}0.127 \\
(0.000)\end{array}$ & *** \\
\hline Tender offer & $\begin{array}{r}1.886 \\
(0.000)\end{array}$ & $* * *$ & $\begin{array}{r}1.903 \\
(0.000)\end{array}$ & $* * *$ & $\begin{array}{r}1.898 \\
(0.000)\end{array}$ & $* * *$ & $\begin{array}{r}2.019 \\
(0.000)\end{array}$ & $* * *$ & $\begin{array}{r}1.944 \\
(0.000)\end{array}$ & $* * *$ & $\begin{array}{r}1.920 \\
(0.000)\end{array}$ & $* * *$ & $\begin{array}{r}1.884 \\
(0.000)\end{array}$ & $* * *$ & $\begin{array}{r}2.435 \\
(0.000)\end{array}$ & $* * *$ & $\begin{array}{r}2.388 \\
(0.000)\end{array}$ & $* * *$ & $\begin{array}{r}1.910 \\
(0.000)\end{array}$ & $* * *$ \\
\hline Hostile offer & $\begin{array}{r}0.620 \\
(0.005)\end{array}$ & $* * *$ & $\begin{array}{r}0.580 \\
(0.011)\end{array}$ & ** & $\begin{array}{r}0.591 \\
(0.000)\end{array}$ & $* * *$ & $\begin{array}{r}0.588 \\
(0.004)\end{array}$ & $* * *$ & $\begin{array}{r}0.596 \\
(0.008)\end{array}$ & **** & $\begin{array}{r}0.612 \\
(0.000)\end{array}$ & $* * *$ & $\begin{array}{r}0.253 \\
(0.119)\end{array}$ & & $\begin{array}{r}1.313 \\
(0.001)\end{array}$ & $* * *$ & $\begin{array}{r}1.273 \\
(0.001)\end{array}$ & $* * *$ & $\begin{array}{r}0.602 \\
(0.000)\end{array}$ & **** \\
\hline Industry-related offer & $\begin{array}{l}-0.281 \\
(0.016)\end{array}$ & ** & $\begin{array}{l}-0.359 \\
(0.002)\end{array}$ & $* * *$ & $\begin{array}{r}-0.182 \\
(0.027)\end{array}$ & ** & $\begin{array}{r}-0.249 \\
(0.021)\end{array}$ & $* *$ & $\begin{array}{r}-0.237 \\
(0.040)\end{array}$ & ** & $\begin{array}{l}-0.188 \\
(0.022)\end{array}$ & $* *$ & $\begin{array}{l}-0.106 \\
(0.050)\end{array}$ & $* *$ & $\begin{array}{l}-0.508 \\
(0.014)\end{array}$ & $* *$ & $\begin{array}{l}-0.527 \\
(0.011)\end{array}$ & $* *$ & $\begin{array}{l}-0.182 \\
(0.027)\end{array}$ & ** \\
\hline Toehold & $\begin{array}{l}-2.264 \\
(0.055)\end{array}$ & * & $\begin{array}{l}-1.874 \\
(0.113)\end{array}$ & & $\begin{array}{l}-2.634 \\
(0.009)\end{array}$ & $* * *$ & $\begin{array}{l}-1.226 \\
(0.253)\end{array}$ & & $\begin{array}{l}-2.165 \\
(0.074)\end{array}$ & * & $\begin{array}{l}-2.565 \\
(0.013)\end{array}$ & $* *$ & $\begin{array}{l}-1.226 \\
(0.137)\end{array}$ & & $\begin{array}{l}-4.156 \\
(0.040)\end{array}$ & $* *$ & $\begin{array}{r}-3.544 \\
(0.057)\end{array}$ & * & $\begin{array}{l}-2.817 \\
(0.008)\end{array}$ & **** \\
\hline Target $\mathrm{M} / \mathrm{B}$ & $\begin{array}{r}-0.002 \\
(0.692)\end{array}$ & & $\begin{array}{r}0.000 \\
(0.905)\end{array}$ & & $\begin{array}{r}-0.005 \\
(0.262)\end{array}$ & & $\begin{array}{l}-0.002 \\
(0.495)\end{array}$ & & $\begin{array}{r}-0.002 \\
(0.644)\end{array}$ & & $\begin{array}{l}-0.005 \\
(0.256)\end{array}$ & & & & $\begin{array}{l}-0.156 \\
(0.000)\end{array}$ & $* * *$ & $\begin{array}{c}-0.156 \\
(0.000)\end{array}$ & $* * *$ & $\begin{array}{r}-0.005 \\
(0.266)\end{array}$ & \\
\hline Acquirer $\mathrm{M} / \mathrm{B}$ & $\begin{array}{r}-0.028 \\
(0.005)\end{array}$ & **** & $\begin{array}{c}-0.029 \\
(0.005)\end{array}$ & $* * *$ & $\begin{array}{r}-0.017 \\
(0.000)\end{array}$ & $* * *$ & $\begin{array}{r}-0.034 \\
(0.003)\end{array}$ & **** & $\begin{array}{r}-0.033 \\
(0.003)\end{array}$ & $* * *$ & $\begin{array}{r}-0.018 \\
(0.000)\end{array}$ & $* * *$ & $\begin{array}{r}-0.001 \\
(0.012)\end{array}$ & ** & $\begin{array}{r}0.005 \\
(0.715)\end{array}$ & & $\begin{array}{r}0.003 \\
(0.815)\end{array}$ & & $\begin{array}{r}-0.017 \\
(0.000)\end{array}$ & *** \\
\hline Target cash ratio & $\begin{array}{r}-0.321 \\
(0.333)\end{array}$ & & $\begin{array}{r}0.025 \\
(0.938)\end{array}$ & & $\begin{array}{r}-0.396 \\
(0.082)\end{array}$ & * & $\begin{array}{r}-0.395 \\
(0.203)\end{array}$ & & $\begin{array}{r}-0.275 \\
(0.404)\end{array}$ & & $\begin{array}{r}-0.453 \\
(0.044)\end{array}$ & ** & & & $\begin{array}{r}1.578 \\
(0.043)\end{array}$ & $* *$ & $\begin{array}{r}1.485 \\
(0.048)\end{array}$ & $* *$ & $\begin{array}{r}-0.315 \\
(0.173)\end{array}$ & \\
\hline Acquirer cash ratio & $\begin{array}{r}0.238 \\
(0.552)\end{array}$ & & $\begin{array}{r}-0.495 \\
(0.214)\end{array}$ & & $\begin{array}{r}0.409 \\
(0.126)\end{array}$ & & $\begin{array}{r}0.152 \\
(0.682)\end{array}$ & & $\begin{array}{r}0.019 \\
(0.961)\end{array}$ & & $\begin{array}{r}0.333 \\
(0.219)\end{array}$ & & $\begin{array}{r}-0.405 \\
(0.009)\end{array}$ & $* * *$ & $\begin{array}{r}2.455 \\
(0.007)\end{array}$ & $* * *$ & $\begin{array}{r}2.520 \\
(0.005)\end{array}$ & $* * *$ & $\begin{array}{r}0.481 \\
(0.079)\end{array}$ & * \\
\hline Target debt ratio & $\begin{array}{r}-0.288 \\
(0.254)\end{array}$ & & $\begin{array}{r}-0.411 \\
(0.083)\end{array}$ & * & $\begin{array}{l}-0.060 \\
(0.713)\end{array}$ & & $\begin{array}{r}-0.192 \\
(0.431)\end{array}$ & & $\begin{array}{r}-0.126 \\
(0.611)\end{array}$ & & $\begin{array}{r}0.016 \\
(0.921)\end{array}$ & & & & $\begin{array}{r}0.640 \\
(0.123)\end{array}$ & & $\begin{array}{r}0.715 \\
(0.089)\end{array}$ & * & $\begin{array}{r}0.029 \\
(0.863)\end{array}$ & \\
\hline Acquirer debt ratio & $\begin{array}{r}-0.224 \\
(0.531)\end{array}$ & & $\begin{array}{r}0.141 \\
(0.681)\end{array}$ & & $\begin{array}{r}-0.064 \\
(0.755)\end{array}$ & & $\begin{array}{r}0.014 \\
(0.966)\end{array}$ & & $\begin{array}{r}-0.146 \\
(0.686)\end{array}$ & & $\begin{array}{r}0.028 \\
(0.886)\end{array}$ & & $\begin{array}{r}0.087 \\
(0.479)\end{array}$ & & $\begin{array}{r}0.524 \\
(0.404)\end{array}$ & & $\begin{array}{r}0.547 \\
(0.392)\end{array}$ & & $\begin{array}{r}0.021 \\
(0.915)\end{array}$ & \\
\hline Target profitability & -0.117 & & -0.413 & & -0.083 & & 0.011 & & -0.240 & & -0.069 & & & & -1.695 & & -1.862 & $*$ & -0.145 & \\
\hline
\end{tabular}




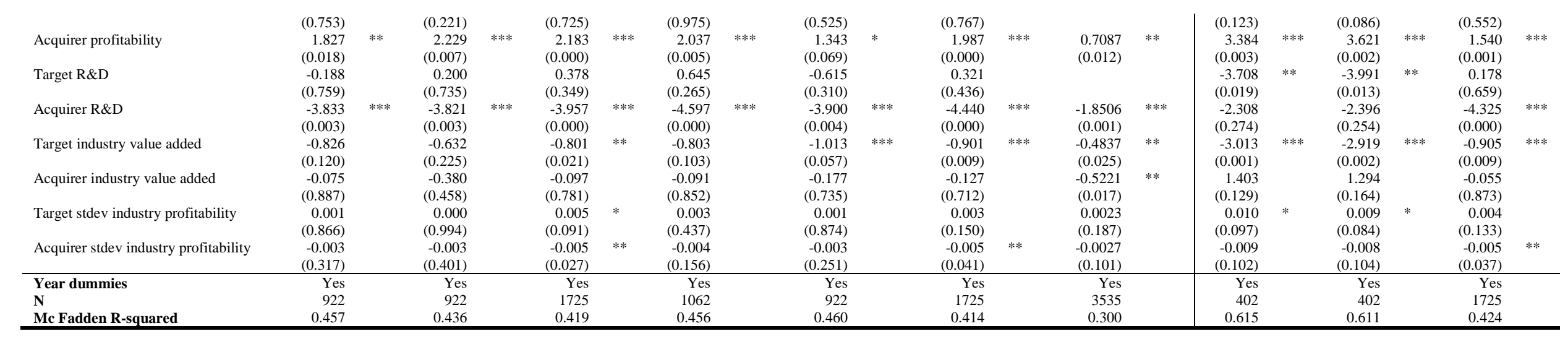




\section{Table V: Choice of payment consideration: two-way terciles}

\section{Panel A: Univariate results}

This table presents the fraction of transactions paid in cash for the top and bottom terciles of target and acquirer information asymmetry and uncertainty. The allocation has been based on the second information asymmetry index (=composite index including the inverse of normalized relative analyst coverage, normalized analyst forecast dispersion, normalized analyst forecast error, the inverse of normalized relative media coverage and normalized firm size) and the uncertainty index (Composite index including implied and idiosyncratic stock return volatility).

\begin{tabular}{|c|c|c|c|}
\hline \multirow{2}{*}{\multicolumn{2}{|c|}{ Fraction of transactions paid in cash }} & \multicolumn{2}{|c|}{ Acquirer information asymmetry } \\
\hline & & HIGH (TOP T) & LOW (BOTTOM T) \\
\hline \multirow{2}{*}{ Target information asymmetry } & HIGH (TOP T) & $37.91 \%$ & $62.90 \%$ \\
\hline & LOW (BOTTOM T) & $31.43 \%$ & $49.38 \%$ \\
\hline & & \multicolumn{2}{|c|}{ p-value for difference } \\
\hline \multirow{2}{*}{\multicolumn{2}{|c|}{$\begin{array}{l}\text { Target high/acquirer high versus target low/acquirer low } \\
\text { Target low/acquirer high versus target high/acquirer low }\end{array}$}} & \multicolumn{2}{|c|}{0.041} \\
\hline & & \multicolumn{2}{|c|}{0.003} \\
\hline & & \multicolumn{2}{|c|}{ Acquirer uncertainty } \\
\hline & & HIGH (TOP T) & LOW (BOTTOM T) \\
\hline \multirow{2}{*}{ Target uncertainty } & HIGH (TOP T) & $16.47 \%$ & $64.29 \%$ \\
\hline & LOW (BOTTOM T) & $50.00 \%$ & $55.05 \%$ \\
\hline & & \multicolumn{2}{|c|}{ p-value for difference } \\
\hline \multicolumn{2}{|c|}{ Target high/acquirer high versus target low/acquirer low } & \multicolumn{2}{|c|}{0.000} \\
\hline \multicolumn{2}{|c|}{ Target low/acquirer high versus target high/acquirer low } & \multicolumn{2}{|c|}{0.719} \\
\hline
\end{tabular}

\section{Panel B: Multivariate results}

This table reports the results of a binary probit regression where the dependent variable equals one in case of a cash offer. Four dummy variables are considered as explanatory variables capturing whether target and bidder are in the bottom or top terciles according to the second information asymmetry index (=composite index including the inverse of normalized relative analyst coverage, normalized analyst forecast dispersion, normalized analyst forecast error, the inverse of normalized relative media coverage and normalized firm size) and the uncertainty index. (Composite index including implied and idiosyncratic stock return volatility). The control variables include the relative size of target versus bidder, dummies capturing respectively whether it is a tender, an hostile or an industryrelated offer (at 4-digit SIC level), the acquirer's toehold in the target, the target's and acquirer's market-to-book ratio of equity, cash ratio (= cash and cash equivalents/total assets), debt ratio (= total debt/total assets), profitability (= EBITDA/total assets), R\&D (= R\&D expenses/total assets), industry value added (= value added/total output), and the standard deviation of profitability in the target's and acquirer's industry. t-statistics are calculated using White heteroscedasticity-consistent standard errors. $p$-values are reported in parentheses.***, ** and * indicate significance at the 1,5 , and $10 \%$ levels, respectively.

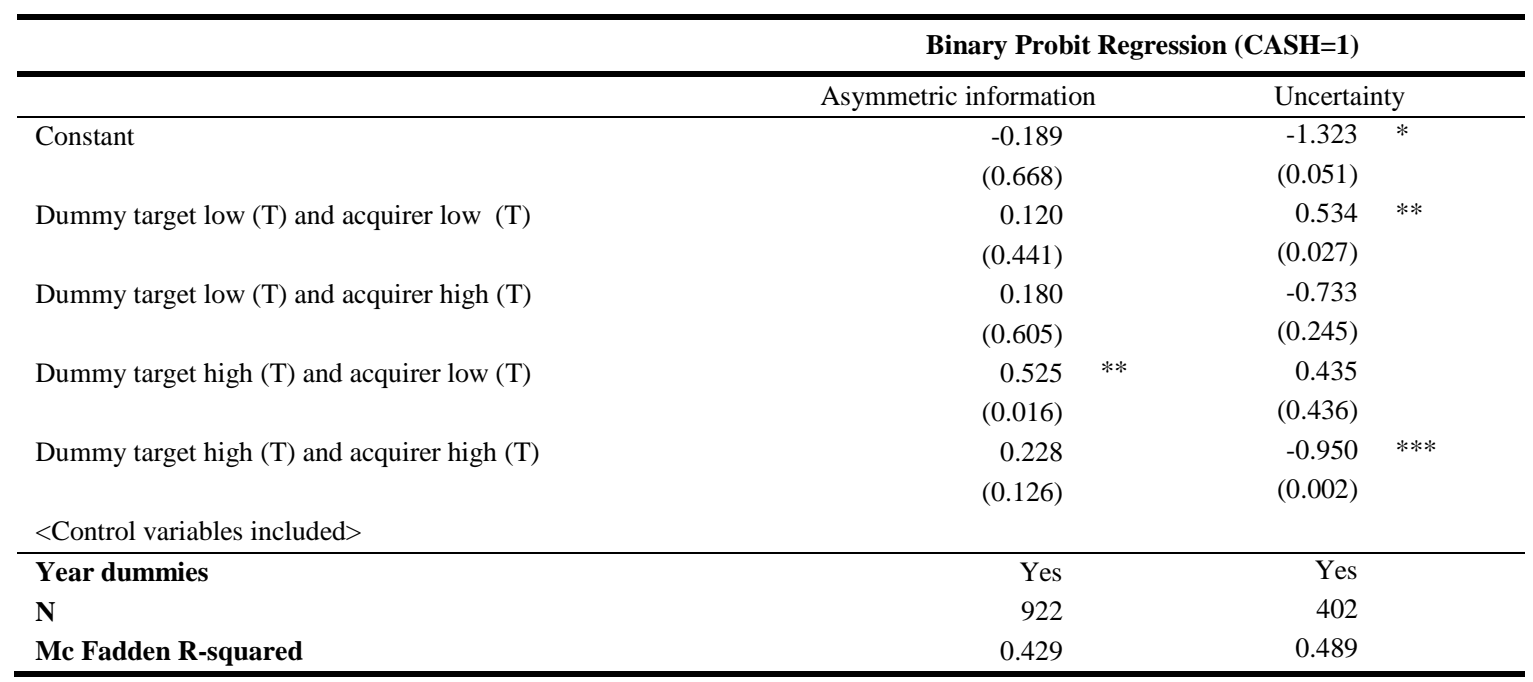




\section{Table VI: Acquirer and target gains}

\section{Panel A: Cumulative abnormal returns}

This panel reports the acquirer and target cumulative abnormal return (CAR) over different windows surrounding the M\&A announcement date (day 0). Expected returns are calculated using the market model, which is estimated during a clean period $[-250,-51]$ relative to the event date (day 0 ). $* * *, * *$ and $*$ indicate significance at the 1,5 , and $10 \%$ levels, respectively.

\begin{tabular}{|c|c|c|c|c|c|}
\hline Event window & {$[0]$} & {$[-1,0]$} & {$[-1,+1]$} & {$[-5,5]$} & {$[-10,+10]$} \\
\hline \multicolumn{6}{|c|}{ Public-Public transactions: } \\
\hline Acquirer CAR (\%) & $-1.36 \% * * *$ & $-1.33 \% * * *$ & $-1.68 \% * * *$ & $-2.02 \% * * *$ & $-2.53 \% * * *$ \\
\hline Target CAR (\%) & $17.02 \% * * *$ & $18.55 \% * * *$ & $24.81 \% * * *$ & $32.10 \% * * *$ & $29.60 \% * * *$ \\
\hline \multicolumn{6}{|c|}{ Public-Private transactions: } \\
\hline Acquirer CAR (\%) & $1.24 \% * * *$ & $1.48 \% * * *$ & $1.75 \% * * *$ & $0.63 \%$ & $-0.63 \%$ \\
\hline
\end{tabular}

\section{Panel B: Division of gains}

Panel B reports the average acquirer relative return as well as the fraction of gains accruing to acquirer shareholders over different event windows. This Panel only reports results for the sample of public targets as return data is needed for both target and acquirer. The relative gain of the acquirer versus the target is calculated as the difference in dollar gains between acquirer and target divided by the sum of the acquirer's and target's pre-M\&A market value of equity. The fraction of acquirer gains equals the percentage of total dollar gains accruing to acquirer shareholders. As results would be misleading if dollar returns are negative for either or both firms, we calculate this fraction for the subsample where both firms realize positive CARs. ***, ** and * indicate significance at the 1,5 , and $10 \%$ levels, respectively.

\begin{tabular}{lccccc}
\hline \multicolumn{1}{c}{ Event window } & {$[0]$} & {$[-1,0]$} & {$[-1,+1]$} & {$[-5,5]$} & {$[-10,+10]$} \\
\hline & & & & & \\
Average acquirer relative return & $-3.18 \% * * *$ & $-3.39 \% * * *$ & $-4.31 \% * * *$ & $-4.83 \% * * *$ & $-5.52 \% * * *$ \\
$\begin{array}{l}\text { (\% positive) } \\
\text { Average acquirer fraction of gains }\end{array}$ & $(31.13 \%)$ & $(30.26 \%)$ & $(28.17 \%)$ & $(44.41 \%)$ & $(44.48 \%)$ \\
& $60.32 \%$ & $60.11 \%$ & $58.25 \%$ & $61.87 \%$ & $62.87 \%$ \\
\hline
\end{tabular}




\section{Table VII: Determinants of acquirer wealth effects}

This table reports the results of OLS regressions with acquirer CAR over the window $[-1,+1]$. The following proxies for target and acquirer information asymmetry are considered as explanatory variables in the model: Composite asymmetric information index 1 (=composite index including the inverse of normalized relative analyst coverage, normalized analyst forecast dispersion, normalized analyst forecast error and the inverse of normalized relative media coverage), Composite asymmetric information index 2 (=composite index including the inverse of normalized relative analyst coverage, normalized analyst forecast dispersion, normalized analyst forecast error, the inverse of normalized relative media coverage and normalized firm size), the inverse of relative analyst coverage (=number of financial analysts/firm size), analyst forecasterror (=absolute value of the difference between median EPS estimate and actual value/stock price), analyst forecast dispersion (=standard deviation $\mathrm{EPS} /$ stock price), he inverse of relative media coverage (=number of Factiva articles in pre-M\&A year/firm size) and a dummy capturing private targets. The degree of uncertainty is captured by implied and idiosyncratic stock return volatility as well as a composite index of both normalized volatility measures. The control variables include the natural logarithm of firm size, the relative size of target versus bidder, dummies capturing respectively whether it is a tender, an hostile or an industryrelated offer (at 4-digit SIC level), the acquirer's toehold in the target, the target's and acquirer's market-to-book ratio of equity (M/B), cash ratio (= cash and cash equivalents/total assets), debt ratio (= total deb//total assets), profitability (=

\begin{tabular}{|c|c|c|c|c|c|c|c|c|c|c|c|c|c|c|c|c|c|c|c|c|}
\hline & \multicolumn{14}{|c|}{ Proxy for information asymmetry } & \multicolumn{6}{|c|}{ Proxy for uncertainty } \\
\hline & \multicolumn{2}{|c|}{$\begin{array}{c}\text { Composite } \\
\text { asymmetric } \\
\text { information } \\
\text { index } 1 \\
\end{array}$} & \multicolumn{2}{|c|}{$\begin{array}{c}\text { Composite } \\
\text { asymmetric } \\
\text { information } \\
\text { index } 2 \\
\end{array}$} & \multicolumn{2}{|c|}{$\begin{array}{l}\text { Inverse of } \\
\text { relative analyst } \\
\text { coverage }\end{array}$} & \multicolumn{2}{|c|}{$\begin{array}{c}\text { Analyst } \\
\text { forecast error }\end{array}$} & \multicolumn{2}{|c|}{$\begin{array}{c}\text { Analyst } \\
\text { forecast } \\
\text { dispersion }\end{array}$} & \multicolumn{2}{|c|}{$\begin{array}{c}\text { Inverse of } \\
\text { relative media } \\
\text { coverage }\end{array}$} & \multicolumn{2}{|c|}{$\begin{array}{c}\text { Private target } \\
\text { dummy }\end{array}$} & \multicolumn{2}{|c|}{$\begin{array}{c}\text { Composite } \\
\text { uncertainty } \\
\text { index }\end{array}$} & \multicolumn{2}{|c|}{$\begin{array}{c}\text { Implied } \\
\text { volatility }\end{array}$} & \multicolumn{2}{|c|}{$\begin{array}{c}\text { Idiosyncratic } \\
\text { volatility }\end{array}$} \\
\hline Constant & $\begin{array}{r}0.047 \\
(0.156)\end{array}$ & & $\begin{array}{r}0.000 \\
(0.991)\end{array}$ & & $\begin{array}{l}0.016 \\
(0.381)\end{array}$ & & $\begin{array}{l}0.014 \\
(0.503)\end{array}$ & & $\begin{array}{r}0.022 \\
(0.363)\end{array}$ & & $\begin{array}{r}0.022 \\
(0.199)\end{array}$ & & $\begin{array}{r}0.022 \\
(0.151)\end{array}$ & & $\begin{array}{r}0.025 \\
(0.544)\end{array}$ & & $\begin{array}{r}0.048 \\
(0.316)\end{array}$ & & $\begin{array}{r}0.027 \\
(0.138)\end{array}$ & \\
\hline Target information asymmetry & $\begin{array}{r}0.015 \\
(0.116)\end{array}$ & & $\begin{array}{r}0.022 \\
(0.001)\end{array}$ & $* * *$ & $\begin{array}{r}0.009 \\
(0.006)\end{array}$ & $* * *$ & $\begin{array}{r}-0.007 \\
(0.850)\end{array}$ & & $\begin{array}{r}-0.215 \\
(0.497)\end{array}$ & & $\begin{array}{r}-0.000 \\
(0.127)\end{array}$ & & $\begin{array}{r}0.037 \\
(0.000)\end{array}$ & $* * *$ & & & & & & \\
\hline Target uncertainty & & & & & & & & & & & & & & & $\begin{array}{r}-0.024 \\
(0.014)\end{array}$ & $* *$ & $\begin{array}{r}-0.071 \\
(0.013)\end{array}$ & $* *$ & $\begin{array}{r}-0.283 \\
(0.052)\end{array}$ & * \\
\hline Target size & $\begin{array}{r}-0.009 \\
(0.004)\end{array}$ & $* * *$ & & & $\begin{array}{l}-0.007 \\
(0.000)\end{array}$ & $* * *$ & $\begin{array}{r}-0.010 \\
(0.000)\end{array}$ & $* * *$ & $\begin{array}{l}-0.011 \\
(0.000)\end{array}$ & $* * *$ & $\begin{array}{r}-0.009 \\
(0.000)\end{array}$ & $* * *$ & & & $\begin{array}{r}-0.020 \\
(0.000)\end{array}$ & $* * *$ & $\begin{array}{r}-0.020 \\
(0.000)\end{array}$ & $* * *$ & $\begin{array}{l}-0.011 \\
(0.000)\end{array}$ & $* * *$ \\
\hline Stock & $\begin{array}{r}-0.020 \\
(0.014)\end{array}$ & $* *$ & $\begin{array}{r}-0.018 \\
(0.022)\end{array}$ & $* *$ & $\begin{array}{l}-0.034 \\
(0.000)\end{array}$ & $* * *$ & $\begin{array}{r}-0.013 \\
(0.051)\end{array}$ & $*$ & $\begin{array}{l}-0.016 \\
(0.066)\end{array}$ & * & $\begin{array}{r}-0.023 \\
(0.000)\end{array}$ & $* * *$ & $\begin{array}{c}-0.008 \\
(0.080)\end{array}$ & * & $\begin{array}{c}-0.011 \\
(0.355)\end{array}$ & & $\begin{array}{r}0.026 \\
(0.212)\end{array}$ & & $\begin{array}{r}0.002 \\
(0.838)\end{array}$ & \\
\hline Stock*Acquirer information asymmetry & $\begin{array}{l}-0.025 \\
(0.051)\end{array}$ & * & $\begin{array}{l}-0.032 \\
(0.015)\end{array}$ & $* *$ & $\begin{array}{l}-0.012 \\
(0.004)\end{array}$ & $* * *$ & $\begin{array}{r}-0.723 \\
(0.575)\end{array}$ & & $\begin{array}{l}-1.126 \\
(0.867)\end{array}$ & & $\begin{array}{r}-0.000 \\
(0.006)\end{array}$ & $* * *$ & & & & & & & & \\
\hline Acquirer information asymmetry & $\begin{array}{r}-0.013 \\
(0.095)\end{array}$ & $*$ & $\begin{array}{l}-0.005 \\
(0.377)\end{array}$ & & $\begin{array}{l}-0.001 \\
(0.779)\end{array}$ & & $\begin{array}{r}0.075 \\
(0.796)\end{array}$ & & $\begin{array}{r}2.084 \\
(0.653)\end{array}$ & & $\begin{array}{r}-0.000 \\
(0.328)\end{array}$ & & & & & & & & & \\
\hline Stock*Acquirer uncertainty & & & & & & & & & & & & & & & $\begin{array}{r}-0.017 \\
(0.099)\end{array}$ & * & $\begin{array}{r}-0.083 \\
(0.072)\end{array}$ & * & $\begin{array}{c}-0.635 \\
(0.069)\end{array}$ & * \\
\hline Acquirer uncertainty & & & & & & & & & & & & & & & $\begin{array}{r}0.006 \\
(0.604)\end{array}$ & & $\begin{array}{r}0.038 \\
(0.412)\end{array}$ & & $\begin{array}{r}0.314 \\
(0.299)\end{array}$ & \\
\hline Acquirer size & $\begin{array}{r}0.000 \\
(0.963)\end{array}$ & & & & $\begin{array}{r}0.002 \\
(0.214)\end{array}$ & & $\begin{array}{r}0.002 \\
(0.504)\end{array}$ & & $\begin{array}{r}0.003 \\
(0.264)\end{array}$ & & $\begin{array}{r}0.002 \\
(0.330)\end{array}$ & & $\begin{array}{r}-0.004 \\
(0.000)\end{array}$ & $* * *$ & $\begin{array}{r}0.010 \\
(0.041)\end{array}$ & $* *$ & $\begin{array}{r}0.010 \\
(0.034)\end{array}$ & $* *$ & $\begin{array}{r}0.003 \\
(0.076)\end{array}$ & $*$ \\
\hline Target size/Acquirer size & $\begin{array}{l}-0.017 \\
(0.146)\end{array}$ & & $\begin{array}{r}-0.020 \\
(0.028)\end{array}$ & ** & $\begin{array}{r}-0.002 \\
(0.509)\end{array}$ & & $\begin{array}{r}-0.018 \\
(0.101)\end{array}$ & & $\begin{array}{r}-0.017 \\
(0.160)\end{array}$ & & $\begin{array}{r}-0.002 \\
(0.475)\end{array}$ & & & & $\begin{array}{r}0.006 \\
(0.673)\end{array}$ & & $\begin{array}{r}0.006 \\
(0.686)\end{array}$ & & $\begin{array}{r}-0.002 \\
(0.478)\end{array}$ & \\
\hline Tender offer & $\begin{array}{r}0.012 \\
(0.062)\end{array}$ & * & $\begin{array}{r}0.013 \\
(0.049)\end{array}$ & ** & $\begin{array}{r}0.017 \\
(0.000)\end{array}$ & $* * *$ & $\begin{array}{r}0.014 \\
(0.013)\end{array}$ & ** & $\begin{array}{r}0.011 \\
(0.071)\end{array}$ & * & $\begin{array}{r}0.017 \\
(0.000)\end{array}$ & $* * *$ & $\begin{array}{r}0.027 \\
(0.000)\end{array}$ & $* * *$ & $\begin{array}{r}0.006 \\
(0.526)\end{array}$ & & $\begin{array}{r}0.006 \\
(0.556)\end{array}$ & & $\begin{array}{r}0.017 \\
(0.000)\end{array}$ & $* * *$ \\
\hline Hostile offer & $\begin{array}{r}0.011 \\
(0.174)\end{array}$ & & $\begin{array}{r}0.007 \\
(0.406)\end{array}$ & & $\begin{array}{r}0.005 \\
(0.375)\end{array}$ & & $\begin{array}{r}0.009 \\
(0.204)\end{array}$ & & $\begin{array}{r}0.009 \\
(0.246)\end{array}$ & & $\begin{array}{r}0.006 \\
(0.307)\end{array}$ & & $\begin{array}{r}0.000 \\
(0.935)\end{array}$ & & $\begin{array}{r}0.002 \\
(0.877)\end{array}$ & & $\begin{array}{r}0.003 \\
(0.824)\end{array}$ & & $\begin{array}{r}0.005 \\
(0.407)\end{array}$ & \\
\hline Industry-related offer & 0.002 & & 0.000 & & $\begin{array}{r}0.001 \\
(0.859)\end{array}$ & & $\begin{array}{r}0.003 \\
(0.529)\end{array}$ & & $\begin{array}{r}0.002 \\
(0.687)\end{array}$ & & $\begin{array}{r}0.001 \\
0.846\end{array}$ & & $\begin{array}{r}-0.001 \\
(0.813)\end{array}$ & & $\begin{array}{r}-0.005 \\
-0.517)\end{array}$ & & $\begin{array}{r}-0.005 \\
(0.499)\end{array}$ & & 0.000 & \\
\hline Toehold & 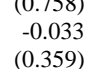 & & $\begin{array}{r}(0.940) \\
-0.034 \\
(0.353)\end{array}$ & & $\begin{array}{r}(0.889) \\
0.034 \\
(0.151)\end{array}$ & & $\begin{array}{r}(0.529) \\
-0.013 \\
(0.681)\end{array}$ & & $\begin{array}{r}(0.08 /) \\
-0.037 \\
(0.274)\end{array}$ & & $\begin{array}{r}(0.846) \\
0.029 \\
(0.231)\end{array}$ & & $\begin{array}{r}(0.813) \\
0.014 \\
(0.521)\end{array}$ & & $\begin{array}{r}(0.517) \\
0.028 \\
(0.626)\end{array}$ & & $\begin{array}{r}(0.499) \\
0.022 \\
(0.713)\end{array}$ & & $\begin{array}{r}(0.919) \\
0.038 \\
(0.125)\end{array}$ & \\
\hline Target $\mathrm{M} / \mathrm{B}$ & 0.000 & & 0.000 & & $\begin{array}{r}0.000 \\
(0.548)\end{array}$ & & $\begin{array}{r}-0.000 \\
(0.444)\end{array}$ & & $\begin{array}{r}0.000 \\
(0.643)\end{array}$ & & 0.000 & & & & 0.000 & $* *$ & 0.000 & $* *$ & 0.000 & \\
\hline Acquirer $\mathrm{M} / \mathrm{B}$ & $\begin{array}{l}(0.930) \\
-0.001 \\
(0.102)\end{array}$ & & $\begin{array}{r}(0.922) \\
-0.001 \\
(0.184)\end{array}$ & & $\begin{array}{l}(0.5 .58) \\
-0.000 \\
(0.408)\end{array}$ & & $\begin{array}{r}(0.444) \\
-0.001 \\
(0.122)\end{array}$ & & $\begin{array}{r}(0.643) \\
-0.001 \\
(0.206)\end{array}$ & & $\begin{array}{r}(0.291) \\
-0.000 \\
(0.438)\end{array}$ & & $\begin{array}{r}0.000 \\
(0.071)\end{array}$ & * & $\begin{array}{r}(0.034) \\
-0.001 \\
(0.195)\end{array}$ & & $\begin{array}{r}(0.021) \\
-0.001 \\
(0.187)\end{array}$ & & $\begin{array}{l}(0.340) \\
-0.000 \\
(0.426)\end{array}$ & \\
\hline Target cash ratio & $\begin{array}{r}-0.021 \\
(0.224)\end{array}$ & & $\begin{array}{r}-0.013 \\
(0.420)\end{array}$ & & $\begin{array}{l}-0.037 \\
(0.003)\end{array}$ & $* * *$ & $\begin{array}{r}-0.021 \\
(0.189)\end{array}$ & & $\begin{array}{r}-0.022 \\
(0.194)\end{array}$ & & $\begin{array}{r}-0.042 \\
(0.001)\end{array}$ & $* * *$ & & & $\begin{array}{r}-0.033 \\
(0.196)\end{array}$ & & $\begin{array}{r}-0.038 \\
(0.139)\end{array}$ & & $\begin{array}{l}-0.040 \\
(0.001)\end{array}$ & $* * *$ \\
\hline
\end{tabular}




\begin{tabular}{|c|c|c|c|c|c|c|c|c|c|c|c|c|c|c|c|}
\hline Acquirer cash ratio & -0.037 & -0.033 & -0.038 & -0.031 & & -0.032 & & -0.041 & $* * *$ & -0.043 & $* * *$ & -0.024 & -0.023 & -0.035 & $* *$ \\
\hline & $(0.100)$ & $(0.143)$ & $(0.012)$ & $(0.131)$ & & $(0.149)$ & & $(0.009)$ & & $(0.000)$ & & $(0.508)$ & $(0.506)$ & $(0.022)$ & \\
\hline \multirow[t]{2}{*}{ Target debt ratio } & -0.004 & -0.013 & -0.004 & 0.001 & & 0.002 & & -0.002 & & & & 0.012 & 0.012 & 0.000 & \\
\hline & $(0.763)$ & $(0.252)$ & $(0.663)$ & $(0.907)$ & & $(0.901)$ & & $(0.834)$ & & & & $(0.396)$ & $(0.414)$ & $(0.997)$ & \\
\hline \multirow{2}{*}{ Acquirer debt ratio } & 0.030 & 0.021 & 0.010 & 0.026 & & 0.021 & & 0.010 & & 0.001 & & 0.013 & 0.017 & 0.008 & \\
\hline & $(0.127)$ & $(0.277)$ & $(0.373)$ & $(0.114)$ & & $(0.272)$ & & $(0.410)$ & & $(0.872)$ & & $(0.630)$ & $(0.534)$ & $(0.520)$ & \\
\hline \multirow[t]{2}{*}{ Target profitability } & -0.016 & -0.025 & -0.008 & -0.013 & & -0.024 & & -0.009 & & & & -0.024 & -0.021 & -0.016 & \\
\hline & $(0.511)$ & $(0.309)$ & $(0.556)$ & $(0.502)$ & & $(0.308)$ & & $(0.518)$ & & & & $(0.537)$ & $(0.591)$ & $(0.224)$ & \\
\hline \multirow{2}{*}{ Acquirer profitability } & -0.032 & -0.027 & -0.005 & -0.023 & & -0.023 & & 0.003 & & -0.019 & & 0.030 & 0.034 & 0.000 & \\
\hline & $(0.284)$ & $(0.376)$ & $(0.801)$ & $(0.427)$ & & $(0.430)$ & & $(0.861)$ & & $(0.102)$ & & $(0.459)$ & $(0.405)$ & $(0.997)$ & \\
\hline \multirow[t]{2}{*}{ Target R\&D } & -0.008 & 0.010 & 0.029 & 0.008 & & -0.008 & & 0.028 & & & & 0.000 & 0.011 & 0.021 & \\
\hline & $(0.821)$ & $(0.787)$ & $(0.195)$ & $(0.791)$ & & $(0.807)$ & & $(0.214)$ & & & & $(0.996)$ & $(0.839)$ & $(0.362)$ & \\
\hline \multirow{2}{*}{ Acquirer R\&D } & -0.017 & -0.015 & 0.013 & -0.025 & & -0.003 & & 0.014 & & -0.018 & & 0.097 & 0.098 & 0.019 & \\
\hline & $(0.823)$ & $(0.843)$ & $(0.796)$ & $(0.720)$ & & $(0.968)$ & & $(0.777)$ & & $(0.489)$ & & $(0.259)$ & $(0.258)$ & $(0.692)$ & \\
\hline \multirow[t]{2}{*}{ Target industry value added } & -0.001 & 0.004 & 0.015 & 0.004 & & 0.001 & & 0.011 & & -0.017 & & -0.011 & -0.009 & 0.009 & \\
\hline & $(0.957)$ & $(0.858)$ & $(0.413)$ & $(0.850)$ & & $(0.981)$ & & $(0.550)$ & & $(0.282)$ & & $(0.755)$ & $(0.811)$ & $(0.643)$ & \\
\hline \multirow{2}{*}{ Acquirer industry value added } & 0.042 & $\begin{array}{r}(.030) \\
0.042\end{array}$ & 0.020 & 0.049 & $* *$ & 0.044 & $* *$ & 0.022 & & 0.021 & & 0.024 & 0.020 & 0.019 & \\
\hline & $(0.062)$ & $(0.064)$ & $(0.286)$ & $(0.018)$ & & $(0.050)$ & & $(0.246)$ & & $(0.143)$ & & $(0.505)$ & $(0.565)$ & $(0.300)$ & \\
\hline \multirow{2}{*}{ Target stdev industry profitability } & 0.000 & 0.000 & 0.000 & 0.000 & & 0.000 & & -0.000 & & 0.000 & & 0.000 & 0.000 & 0.000 & \\
\hline & $(0.914)$ & $(0.992)$ & $(0.800)$ & $(0.824)$ & & $(0.712)$ & & $(0.748)$ & & $(0.743)$ & & $(0.504)$ & $(0.544)$ & $(0.886)$ & \\
\hline \multirow[t]{2}{*}{ Acquirer stdev industry profitability } & -0.000 & -0.000 & -0.000 & -0.000 & & -0.000 & & -0.000 & & 0.000 & & 0.000 & 0.000 & -0.000 & \\
\hline & $(0.515)$ & $(0.704)$ & $(0.447)$ & $(0.523)$ & & $(0.389)$ & & $(0.486)$ & & $(0.779)$ & & $(0.813)$ & $(0.836)$ & $(0.397)$ & \\
\hline Year dummies & Yes & Yes & Yes & Yes & & Yes & & Yes & & Yes & & Yes & Yes & Yes & \\
\hline $\mathbf{N}$ & 922 & 922 & 1725 & 1062 & & 922 & & 1725 & & 3535 & & 402 & 422 & 1725 & \\
\hline Adjusted R-squared & 0.123 & 0.113 & 0.098 & 0.113 & & 0.114 & & 0.126 & & 0.051 & & 0.162 & 0.156 & 0.094 & \\
\hline
\end{tabular}


Table VIII: Determinants of division of gains

This table reports the results of OLS regression models estimating the acquirer relative return (Panel A) and fraction of acquirer returns (Panel B). The following proxies for target and acquirer information asymmetry are considered as explanatory variables in the model: Composite asymmetric information index 1 (=composite index including the inverse of normalized relative analyst coverage, normalized analyst forecast dispersion, normalized analyst forecast error and the inverse of normalized relative media coverage), Composite asymmetric information index 2 (=composite index including the inverse of normalized relative analyst coverage, normalized analyst forecast dispersion, normalized analyst forecast error, the inverse of normalized relative media coverage and normalized firm size), the inverse of relative analyst coverage (=number of financial analyst/firm size), analyst forecast enor (=absolute value of the diference between median ERS estimate and actual value/stock price), analyst forecast dispersion (-standard deviation ERS/tock price), the volatility measures. The control variables include the natural logarithm of firm size, the relative size of target versus bidder, dummies capturing respectively whether it is a tender, an hostile or an industry-related offer (at 4 -digit SIC level), the acquirer's tohohold in the target, the target's and acquirer's market-to-book ratio of equity $(\mathrm{M} / \mathrm{B})$, cash ratio ( $=$ cash and cash equivalents/total assets), debt ratio $(=$ total debt/total assets), profitability $(=\mathrm{EBITDA} /$ total assets), R\&D $(=\mathrm{R} \& D$ expenses/total assets $)$, industry value added $(=$ value added/total output), and the standard deviation of profitability in the target's and acquirer's industry. t-statistics are calculated using White heteroscedasticity-consistent standard errors. p-values are reported in parentheses.***, ***and * indicate significance at the 1, 5 , and $10 \%$ levels, respectively.

\section{Panel A: Acquirer relative returns}

\begin{tabular}{|c|c|c|c|c|c|c|c|c|c|c|c|c|c|c|c|c|c|c|}
\hline \multirow[b]{3}{*}{ Constant } & \multicolumn{12}{|c|}{ Proxy for information asymmetry } & \multicolumn{6}{|c|}{ Proxy for uncertainty } \\
\hline & \multicolumn{2}{|c|}{$\begin{array}{c}\text { Composite } \\
\text { asymmetric } \\
\text { information } \\
\text { index } 1\end{array}$} & \multicolumn{2}{|c|}{$\begin{array}{c}\text { Composite } \\
\text { asymmetric } \\
\text { information } \\
\text { index } 2\end{array}$} & \multicolumn{2}{|c|}{$\begin{array}{l}\text { Inverse of } \\
\text { relative analyst } \\
\text { coverage }\end{array}$} & \multicolumn{2}{|c|}{$\begin{array}{c}\text { Analyst } \\
\text { forecast error }\end{array}$} & \multicolumn{2}{|c|}{$\begin{array}{c}\text { Analyst } \\
\text { forecast } \\
\text { dispersion }\end{array}$} & \multicolumn{2}{|c|}{$\begin{array}{l}\text { Inverse of } \\
\text { relative media } \\
\text { coverage }\end{array}$} & \multicolumn{2}{|c|}{$\begin{array}{l}\text { Composite } \\
\text { uncertainty } \\
\text { index }\end{array}$} & \multicolumn{2}{|c|}{$\begin{array}{l}\text { Implied } \\
\text { volatility }\end{array}$} & \multicolumn{2}{|c|}{$\begin{array}{l}\text { Idiosyncratic } \\
\text { volatility }\end{array}$} \\
\hline & $\begin{array}{l}-0.040 \\
(0.132)\end{array}$ & & $\begin{array}{r}-0.042 \\
(0.070)\end{array}$ & * & $\begin{array}{l}-0.041 \\
(0.018)\end{array}$ & $* * *$ & $\begin{array}{r}-0.053 \\
(0.012)\end{array}$ & $* *$ & $\begin{array}{l}-0.045 \\
(0.052)\end{array}$ & * & $\begin{array}{l}-0.0360 \\
(0.038)\end{array}$ & *** & $\begin{array}{l}-0.028 \\
(0.498)\end{array}$ & & $\begin{array}{l}-0.004 \\
(0.927)\end{array}$ & & $\begin{array}{l}-0.047 \\
(0.009)\end{array}$ & $* * *$ \\
\hline Target information asymmetry & $\begin{array}{r}0.019 \\
(0.037)\end{array}$ & $* *$ & $\begin{array}{r}0.026 \\
(0.000)\end{array}$ & $* * *$ & $\begin{array}{r}0.012 \\
(0.000)\end{array}$ & $* * *$ & $\begin{array}{r}0.012 \\
(0.686)\end{array}$ & & $\begin{array}{l}-0.031 \\
(0.927)\end{array}$ & & $\begin{array}{l}0.0000 \\
(0.173)\end{array}$ & & & & & & & \\
\hline Target uncertainty & & & & & & & & & & & & & $\begin{array}{l}-0.019 \\
(0.064)\end{array}$ & * & $\begin{array}{l}-0.032 \\
(0.205)\end{array}$ & & $\begin{array}{r}0.022 \\
(0.870)\end{array}$ & \\
\hline Target size & $\begin{array}{l}-0.016 \\
(0.000)\end{array}$ & $* * *$ & & & $\begin{array}{r}-0.014 \\
(0.000)\end{array}$ & $* * *$ & $\begin{array}{l}-0.017 \\
(0.000)\end{array}$ & $* * *$ & $\begin{array}{l}-0.018 \\
(0.000)\end{array}$ & $* * *$ & $\begin{array}{l}-0.0164 \\
(0.000)\end{array}$ & $* * *$ & $\begin{array}{l}-0.019 \\
(0.000)\end{array}$ & *** & $\begin{array}{l}-0.017 \\
(0.000)\end{array}$ & **** & $\begin{array}{r}-0.017 \\
(0.000)\end{array}$ & *** \\
\hline Stock & $\begin{array}{r}0.000 \\
(0.993)\end{array}$ & & $\begin{array}{r}0.000 \\
(0.971)\end{array}$ & & $\begin{array}{r}-0.002 \\
(0.724)\end{array}$ & & $\begin{array}{r}-0.002 \\
(0.679)\end{array}$ & & $\begin{array}{l}-0.001 \\
(0.898)\end{array}$ & & $\begin{array}{l}-0.0027 \\
(0.590)\end{array}$ & & $\begin{array}{r}0.006 \\
(0.555)\end{array}$ & & $\begin{array}{r}0.004 \\
(0.699)\end{array}$ & & $\begin{array}{r}-0.003 \\
(0.515)\end{array}$ & \\
\hline Acquirer information asymmetry & $\begin{array}{l}-0.016 \\
(0.020)\end{array}$ & $* *$ & $\begin{array}{l}-0.027 \\
(0.000)\end{array}$ & $* * *$ & $\begin{array}{l}-0.010 \\
(0.000)\end{array}$ & $* * *$ & $\begin{array}{r}0.042 \\
(0.609)\end{array}$ & & $\begin{array}{r}1.251 \\
(0.644)\end{array}$ & & $\begin{array}{l}0.0000 \\
(0.144)\end{array}$ & & & & & & & \\
\hline Acquirer uncertainty & & & & & & & & & & & & & $\begin{array}{l}-0.000 \\
(0.973)\end{array}$ & & $\begin{array}{r}-0.015 \\
(0.612)\end{array}$ & & $\begin{array}{r}0.136 \\
(0.509)\end{array}$ & \\
\hline Acquirer size & $\begin{array}{r}0.011 \\
(0.000)\end{array}$ & $* * *$ & & & $\begin{array}{r}0.009 \\
(0.000)\end{array}$ & $* * *$ & $\begin{array}{r}0.011 \\
(0.000)\end{array}$ & $* * *$ & $\begin{array}{r}0.013 \\
(0.000)\end{array}$ & $* * *$ & $\begin{array}{l}0.0106 \\
(0.000)\end{array}$ & $* * *$ & $\begin{array}{r}0.015 \\
(0.001)\end{array}$ & *** & $\begin{array}{r}0.014 \\
(0.001)\end{array}$ & **** & $\begin{array}{r}0.012 \\
(0.000)\end{array}$ & *** \\
\hline Target size/Acquirer size & $\begin{array}{l}-0.007 \\
(0.243)\end{array}$ & & $\begin{array}{r}-0.021 \\
(0.000)\end{array}$ & $* * *$ & $\begin{array}{r}0.000 \\
(0.931)\end{array}$ & & $\begin{array}{r}-0.009 \\
(0.110)\end{array}$ & & $\begin{array}{l}-0.006 \\
(0.320)\end{array}$ & & $\begin{array}{r}0.0002 \\
(0.914)\end{array}$ & & $\begin{array}{l}-0.007 \\
(0.589)\end{array}$ & & $\begin{array}{l}-0.007 \\
(0.589)\end{array}$ & & $\begin{array}{r}0.000 \\
(0.854)\end{array}$ & \\
\hline Tender offer & $\begin{array}{r}0.006 \\
(0.346)\end{array}$ & & $\begin{array}{r}0.010 \\
(0.092)\end{array}$ & * & $\begin{array}{r}0.003 \\
(0.470)\end{array}$ & & $\begin{array}{r}0.006 \\
(0.287)\end{array}$ & & $\begin{array}{r}0.005 \\
(0.377)\end{array}$ & & $\begin{array}{l}0.0030 \\
(0.525)\end{array}$ & & $\begin{array}{l}-0.008 \\
(0.434)\end{array}$ & & $\begin{array}{l}-0.008 \\
(0.429)\end{array}$ & & $\begin{array}{r}0.003 \\
(0.538)\end{array}$ & \\
\hline Hostile offer & $\begin{array}{r}-0.005 \\
(0.501)\end{array}$ & & $\begin{array}{r}-0.011 \\
(0.134)\end{array}$ & & $\begin{array}{r}-0.008 \\
(0.243)\end{array}$ & & $\begin{array}{r}-0.005 \\
(0.428)\end{array}$ & & $\begin{array}{l}-0.007 \\
(0.342)\end{array}$ & & $\begin{array}{l}-0.0077 \\
(0.236)\end{array}$ & & $\begin{array}{l}-0.011 \\
-0.357\end{array}$ & & $\begin{array}{r}-0.010 \\
(0.411)\end{array}$ & & $\begin{array}{l}-0.008 \\
(0.225\end{array}$ & \\
\hline Industry-related offer & $\begin{array}{r}0.002 \\
(0.687)\end{array}$ & & $\begin{array}{r}-0.002 \\
-0.728)\end{array}$ & & $\begin{array}{r}-0.003 \\
-0.533)\end{array}$ & & $\begin{array}{r}(0.420) \\
0.000 \\
(0.971)\end{array}$ & & $\begin{array}{r}0.002 \\
0.698)\end{array}$ & & $\begin{array}{r}-0.0014 \\
(0.722)\end{array}$ & & $\begin{array}{r}0.003 \\
(0.658)\end{array}$ & & $\begin{array}{r}0.004 \\
(0.636)\end{array}$ & & $\begin{array}{l}-0.002 \\
(0.693)\end{array}$ & \\
\hline Toehold & $\begin{array}{r}0.015 \\
(0.678)\end{array}$ & & $\begin{array}{r}0.028 \\
(0.412)\end{array}$ & & $\begin{array}{r}0.044 \\
(0.231)\end{array}$ & & $\begin{array}{r}0.027 \\
(0.406)\end{array}$ & & $\begin{array}{r}0.013 \\
(0.711)\end{array}$ & & $\begin{array}{r}0.0439 \\
(0.238)\end{array}$ & & $\begin{array}{r}0.018 \\
(0.631)\end{array}$ & & $\begin{array}{r}0.013 \\
(0.754)\end{array}$ & & $\begin{array}{r}0.046 \\
(0.216)\end{array}$ & \\
\hline Target $\mathrm{M} / \mathrm{B}$ & $\begin{array}{r}0.000 \\
(0.697)\end{array}$ & & $\begin{array}{r}0.000 \\
(0.998)\end{array}$ & & $\begin{array}{r}0.000 \\
(0.000)\end{array}$ & $* * *$ & $\begin{array}{r}0.000 \\
(0.565)\end{array}$ & & $\begin{array}{r}-0.000 \\
(0.378)\end{array}$ & & $\begin{array}{l}0.0000 \\
(0.001)\end{array}$ & $* * *$ & $\begin{array}{r}0.000 \\
(0.000)\end{array}$ & **** & $\begin{array}{r}0.000 \\
(0.000)\end{array}$ & **** & $\begin{array}{r}0.000 \\
(0.001)\end{array}$ & $* * *$ \\
\hline Acquirer $\mathrm{M} / \mathrm{B}$ & $\begin{array}{r}0.001 \\
(0.163)\end{array}$ & & $\begin{array}{r}0.001 \\
(0.120)\end{array}$ & & $\begin{array}{r}0.000 \\
(0.369)\end{array}$ & & $\begin{array}{r}0.001 \\
(0.173)\end{array}$ & & $\begin{array}{r}0.001 \\
(0.123)\end{array}$ & & $\begin{array}{c}0.0001 \\
(0.245)\end{array}$ & & $\begin{array}{r}0.000 \\
(0.476)\end{array}$ & & $\begin{array}{r}0.000 \\
(0.519)\end{array}$ & & $\begin{array}{r}0.000 \\
(0.191)\end{array}$ & \\
\hline Target cash ratio & $\begin{array}{r}-0.011 \\
(0.460)\end{array}$ & & $\begin{array}{r}0.006 \\
(0.694)\end{array}$ & & $\begin{array}{r}-0.019 \\
(0.097)\end{array}$ & * & $\begin{array}{r}-0.010 \\
(0.484)\end{array}$ & & $\begin{array}{r}-0.013 \\
(0.399)\end{array}$ & & $\begin{array}{r}-0.0226 \\
(0.041)\end{array}$ & ** & $\begin{array}{r}-0.042 \\
(0.071)\end{array}$ & * & $\begin{array}{l}-0.046 \\
(0.050)\end{array}$ & ** & $\begin{array}{r}-0.023 \\
(0.035)\end{array}$ & ** \\
\hline Acquirer cash ratio & $\begin{array}{r}-0.032 \\
(0.117)\end{array}$ & & $\begin{array}{r}-0.051 \\
(0.013)\end{array}$ & *** & $\begin{array}{r}-0.027 \\
(0.077)\end{array}$ & * & $\begin{array}{r}-0.023 \\
(0.214)\end{array}$ & & $\begin{array}{l}-0.027 \\
(0.185)\end{array}$ & & $\begin{array}{r}-0.0265 \\
(0.095)\end{array}$ & & $\begin{array}{l}-0.005 \\
(0.875)\end{array}$ & & $\begin{array}{r}-0.006 \\
(0.845)\end{array}$ & & $\begin{array}{r}-0.026 \\
(0.107)\end{array}$ & \\
\hline Target debt ratio & -0.004 & & -0.013 & & 0.007 & & 0.007 & & 0.002 & & 0.0101 & & -0.005 & & -0.006 & & 0.010 & \\
\hline
\end{tabular}




\begin{tabular}{|c|c|c|c|c|c|c|c|c|c|c|c|}
\hline \multirow{3}{*}{ Acquirer debt ratio } & $(0.750)$ & $(0.216)$ & $(0.398)$ & $(0.457)$ & $(0.861)$ & $(0.210)$ & & $(0.666)$ & & $(0.644)$ & $(0.223)$ \\
\hline & -0.002 & 0.002 & -0.009 & -0.002 & -0.007 & -0.0139 & & -0.014 & & -0.012 & -0.014 \\
\hline & $(0.902)$ & $(0.905)$ & $(0.352)$ & $(0.884)$ & $(0.673)$ & $(0.165)$ & & $(0.554)$ & & $(0.610)$ & $(0.164)$ \\
\hline \multirow[t]{2}{*}{ Target profitability } & -0.001 & -0.015 & -0.014 & -0.002 & -0.013 & -0.0156 & & -0.075 & $* *$ & -0.063 & -0.015 \\
\hline & $(0.936)$ & $(0.422)$ & $(0.255)$ & $(0.893)$ & $(0.479)$ & $(0.199)$ & & $(0.037)$ & & $(0.064)$ & $(0.218)$ \\
\hline \multirow[t]{2}{*}{ Acquirer profitability } & -0.026 & -0.010 & 0.014 & -0.015 & -0.022 & 0.0247 & * & 0.024 & & 0.021 & 0.028 \\
\hline & $(0.309)$ & $(0.702)$ & $(0.351)$ & $(0.571)$ & $(0.385)$ & $(0.093)$ & & $(0.505)$ & & $(0.542)$ & $(0.053)$ \\
\hline \multirow[t]{2}{*}{ Target R\&D } & -0.010 & 0.019 & -0.006 & 0.001 & -0.015 & -0.0098 & & -0.038 & & -0.026 & -0.010 \\
\hline & $(0.756)$ & $(0.566)$ & $(0.813)$ & $(0.983)$ & $(0.632)$ & $(0.706)$ & & $(0.416)$ & & $(0.582)$ & $(0.698)$ \\
\hline \multirow[t]{2}{*}{ Acquirer R\&D } & -0.081 & -0.084 & -0.016 & -0.070 & -0.076 & -0.0076 & & 0.032 & & 0.026 & -0.004 \\
\hline & $(0.166)$ & $(0.152)$ & $(0.585)$ & $(0.183)$ & $(0.187)$ & $(0.803)$ & & $(0.695)$ & & $(0.748)$ & $(0.892)$ \\
\hline \multirow[t]{2}{*}{ Target industry value added } & 0.009 & 0.018 & 0.014 & 0.015 & 0.010 & 0.0108 & & 0.013 & & 0.013 & 0.012 \\
\hline & $(0.677)$ & $(0.441)$ & $(0.423)$ & $(0.465)$ & $(0.646)$ & $(0.548)$ & & $(0.712)$ & & $(0.722)$ & $(0.507)$ \\
\hline \multirow[t]{2}{*}{ Acquirer industry value added } & 0.024 & 0.017 & 0.023 & 0.031 & 0.023 & 0.0282 & * & 0.015 & & 0.012 & 0.027 \\
\hline & $(0.234)$ & $(0.404)$ & $(0.161)$ & $(0.108)$ & $(0.239)$ & $(0.095)$ & & $(0.655)$ & & $(0.710)$ & $(0.110)$ \\
\hline \multirow[t]{2}{*}{ Target stdev industry profitability } & 0.000 & 0.000 & -0.000 & 0.000 & 0.000 & -0.0001 & & 0.000 & & 0.000 & -0.000 \\
\hline & $(0.677)$ & $(0.686)$ & $(0.747)$ & $(0.352)$ & $(0.469)$ & $(0.736)$ & & $(0.272)$ & & $(0.270)$ & $(0.764)$ \\
\hline \multirow{2}{*}{ Acquirer stdev industry profitability } & -0.000 & -0.000 & -0.000 & -0.000 & -0.000 & -0.0001 & & -0.000 & & -0.000 & -0.000 \\
\hline & $(0.374)$ & $(0.468)$ & $(0.604)$ & $(0.266)$ & $(0.283)$ & $(0.552)$ & & $(0.483)$ & & $(0.445)$ & $(0.555)$ \\
\hline Year dummies & Yes & Yes & Yes & Yes & Yes & Yes & & Yes & & Yes & Yes \\
\hline & 922 & 922 & 1725 & 1062 & 3535 & 1725 & & 402 & & 922 & 422 \\
\hline Adjusted R-squared & 0.172 & 0.136 & 0.098 & 0.113 & 0.051 & 0.126 & & 0.180 & & 0.114 & 0.156 \\
\hline
\end{tabular}




\section{Panel B: Acquirer fraction of total gains}

\begin{tabular}{|c|c|c|c|c|c|c|c|c|c|c|c|c|c|c|c|c|c|c|}
\hline \multirow{4}{*}{ Constant } & \multicolumn{12}{|c|}{ Proxy for information asymmetry } & \multicolumn{6}{|c|}{ Proxy for uncertainty } \\
\hline & \multicolumn{2}{|c|}{$\begin{array}{c}\text { Composite } \\
\text { asymmetric } \\
\text { information } \\
\text { index 1 }\end{array}$} & \multicolumn{2}{|c|}{$\begin{array}{c}\text { Composite } \\
\text { asymmetric } \\
\text { information } \\
\text { index } 2 \\
\end{array}$} & \multicolumn{2}{|c|}{$\begin{array}{l}\text { Inverse of } \\
\text { relative analyst } \\
\text { coverage }\end{array}$} & \multicolumn{2}{|c|}{$\begin{array}{l}\text { Analyst forecast } \\
\text { error }\end{array}$} & \multicolumn{2}{|c|}{$\begin{array}{l}\text { Analyst forecast } \\
\text { dispersion }\end{array}$} & \multicolumn{2}{|c|}{$\begin{array}{c}\text { Inverse of } \\
\text { relative media } \\
\text { coverage }\end{array}$} & \multicolumn{2}{|c|}{$\begin{array}{c}\text { Composite } \\
\text { uncertainty } \\
\text { index }\end{array}$} & \multicolumn{2}{|c|}{$\begin{array}{c}\text { Implied } \\
\text { volatility }\end{array}$} & \multicolumn{2}{|c|}{$\begin{array}{c}\text { Idiosyncratic } \\
\text { volatility }\end{array}$} \\
\hline & 0.483 & $* * *$ & 0.450 & $* * *$ & 0.455 & $* * *$ & 0.349 & $* * *$ & 0.357 & ** & 0.406 & $* * *$ & 0.235 & & 0.228 & & 0.330 & $* * *$ \\
\hline & $(0.003)$ & & $(0.002)$ & & $(0.000)$ & & $(0.003)$ & & $(0.021)$ & & $(0.000)$ & & $(0.499)$ & & $(0.567)$ & & $(0.001)$ & \\
\hline Target information asymmetry & 0.046 & & 0.130 & $* * *$ & 0.005 & & 0.520 & & 0.634 & & -0.001 & & & & & & & \\
\hline Target uncertainty & $(0.229)$ & & $(0.001)$ & & $(0.767)$ & & $(0.113)$ & & $(0.636)$ & & $(0.4 / 6)$ & & $\begin{array}{r}-0.021 \\
(0.716)\end{array}$ & & $\begin{array}{r}0.000 \\
(1.000)\end{array}$ & & $\begin{array}{r}0.973 \\
(0.200)\end{array}$ & \\
\hline Target size & $\begin{array}{l}-0.079 \\
(0.000)\end{array}$ & $* * *$ & & & $\begin{array}{r}-0.087 \\
(0.000)\end{array}$ & $* * * *$ & $\begin{array}{r}-0.086 \\
(0.000)\end{array}$ & $* * *$ & $\begin{array}{r}-0.085 \\
(0.000)\end{array}$ & $* * *$ & $\begin{array}{r}-0.089 \\
(0.000)\end{array}$ & $* * *$ & $\begin{array}{r}-0.076 \\
(0.047)\end{array}$ & $* *$ & $\begin{array}{r}-0.073 \\
(0.064)\end{array}$ & * & $\begin{array}{r}-0.084 \\
(0.000)\end{array}$ & $* * *$ \\
\hline Stock & $\begin{array}{r}0.004 \\
(0.916)\end{array}$ & & $\begin{array}{r}0.019 \\
(0.644)\end{array}$ & & $\begin{array}{r}0.052 \\
(0.061)\end{array}$ & * & $\begin{array}{r}0.015 \\
(0.685)\end{array}$ & & $\begin{array}{r}0.008 \\
(0.850)\end{array}$ & & $\begin{array}{r}0.058 \\
(0.039)\end{array}$ & $* *$ & $\begin{array}{r}-0.045 \\
(0.535)\end{array}$ & & $\begin{array}{r}-0.042 \\
(0.568)\end{array}$ & & $\begin{array}{r}0.058 \\
(0.041)\end{array}$ & $* *$ \\
\hline Acquirer information asymmetry & $\begin{array}{r}-0.117 \\
(0.003)\end{array}$ & $* * *$ & $\begin{array}{r}-0.182 \\
(0.000)\end{array}$ & $* * *$ & $\begin{array}{r}-0.047 \\
(0.000)\end{array}$ & $* * *$ & $\begin{array}{r}-0.725 \\
(0.278)\end{array}$ & & $\begin{array}{r}5.309 \\
(0.469)\end{array}$ & & $\begin{array}{r}-0.000 \\
(0.250)\end{array}$ & & & & & & & \\
\hline Acquirer uncertainty & & & & & & & & & & & & & $\begin{array}{r}0.047 \\
(0.375)\end{array}$ & & $\begin{array}{r}0.075 \\
(0.597)\end{array}$ & & $\begin{array}{r}-0.155 \\
(0.883)\end{array}$ & \\
\hline Acquirer size & $\begin{array}{r}0.059 \\
(0.000)\end{array}$ & $* * *$ & & & $\begin{array}{r}0.064 \\
(0.000)\end{array}$ & $* * * *$ & $\begin{array}{r}0.078 \\
(0.000)\end{array}$ & $* * *$ & $\begin{array}{r}0.078 \\
(0.000)\end{array}$ & $* * *$ & $\begin{array}{r}0.073 \\
(0.000)\end{array}$ & $* * *$ & $\begin{array}{r}0.074 \\
(0.011)\end{array}$ & $* *$ & $\begin{array}{r}0.069 \\
(0.020)\end{array}$ & $* *$ & $\begin{array}{r}0.076 \\
(0.000)\end{array}$ & $* * *$ \\
\hline Target size/Acquirer size & $\begin{array}{r}0.023 \\
0.464)\end{array}$ & & $\begin{array}{r}-0.070 \\
(0.041\end{array}$ & ** & $\begin{array}{r}0.003 \\
(0.519)\end{array}$ & & $\begin{array}{r}0.015 \\
0.643)\end{array}$ & & $\begin{array}{r}0.036 \\
0.256)\end{array}$ & & $\begin{array}{r}0.004 \\
(0.474)\end{array}$ & & $\begin{array}{l}-0.037 \\
0.417)\end{array}$ & & $\begin{array}{r}-0.035 \\
(0.440)\end{array}$ & & $\begin{array}{r}0.004 \\
(0.415)\end{array}$ & \\
\hline Tender offer & $\begin{array}{l}-0.011 \\
(0.729)\end{array}$ & & $\begin{array}{r}0.0175 \\
(0.589)\end{array}$ & & $\begin{array}{r}-0.032 \\
(0.171)\end{array}$ & & $\begin{array}{r}-0.031 \\
(0.290)\end{array}$ & & $\begin{array}{r}-0.020 \\
(0.544)\end{array}$ & & $\begin{array}{r}-0.0347 \\
(0.143)\end{array}$ & & $\begin{array}{r}-0.097 \\
(0.111)\end{array}$ & & $\begin{array}{r}-0.094 \\
(0.124)\end{array}$ & & $\begin{array}{r}-0.035 \\
(0.141)\end{array}$ & \\
\hline Hostile offer & $\begin{array}{l}-0.191 \\
(0.001)\end{array}$ & $* * *$ & $\begin{array}{r}-0.198 \\
(0.001)\end{array}$ & $* * *$ & $\begin{array}{r}-0.127 \\
(0.001)\end{array}$ & $* * *$ & $\begin{array}{r}-0.141 \\
(0.001)\end{array}$ & $* * *$ & $\begin{array}{r}-0.191 \\
(0.000)\end{array}$ & $* * *$ & $\begin{array}{r}-0.131 \\
(0.001)\end{array}$ & $* * *$ & $\begin{array}{r}-0.186 \\
(0.010)\end{array}$ & $* * *$ & $\begin{array}{r}-0.187 \\
(0.011)\end{array}$ & $* * *$ & $\begin{array}{r}-0.127 \\
(0.001)\end{array}$ & $* * *$ \\
\hline Industry-related offer & $\begin{array}{r}0.029 \\
(0.341)\end{array}$ & & $\begin{array}{r}0.009 \\
(0.770)\end{array}$ & & $\begin{array}{r}-0.036 \\
(0.081)\end{array}$ & & $\begin{array}{r}0.003 \\
(0.927)\end{array}$ & & $\begin{array}{r}0.035 \\
(0.277)\end{array}$ & & $\begin{array}{r}-0.029 \\
(0.160)\end{array}$ & & $\begin{array}{r}0.117 \\
(0.023)\end{array}$ & ** & $\begin{array}{r}0.117 \\
(0.025)\end{array}$ & $* *$ & $\begin{array}{l}-0.028 \\
(0.180)\end{array}$ & \\
\hline Toehold & 0.345 & & 0.281 & & 0.275 & & 0.186 & & 0.317 & & 0.236 & & 0.202 & & 0.155 & & $\begin{array}{r}0.215 \\
0.458)\end{array}$ & \\
\hline Target M/B & $\begin{array}{r}(0.579) \\
0.000 \\
(0.648)\end{array}$ & & $\begin{array}{r}(0.682) \\
0.000 \\
(0.223)\end{array}$ & & $\begin{array}{r}(0.296) \\
-0.000 \\
(0.156)\end{array}$ & & $\begin{array}{r}(0.603) \\
0.000 \\
(0.961)\end{array}$ & & $\begin{array}{r}(0.630) \\
0.000 \\
(0.601)\end{array}$ & & $\begin{array}{r}(0.408) \\
0.000 \\
(0.273)\end{array}$ & & $\begin{array}{r}(0.688) \\
0.000 \\
(0.828)\end{array}$ & & $\begin{array}{r}(0.761) \\
0.001 \\
(0.809)\end{array}$ & & $\begin{array}{r}(0.458) \\
0.000 \\
(0.348)\end{array}$ & \\
\hline Acquirer $\mathrm{M} / \mathrm{B}$ & $\begin{array}{r}0.006 \\
(0.000)\end{array}$ & $* * *$ & $\begin{array}{l}0.006^{*} \\
(0.000)\end{array}$ & $* * *$ & $\begin{array}{r}0.001 \\
(0.000)\end{array}$ & $* * *$ & $\begin{array}{r}0.006 \\
(0.000)\end{array}$ & $* * *$ & $\begin{array}{r}0.006 \\
(0.000)\end{array}$ & $* * *$ & $\begin{array}{r}0.002 \\
(0.001)\end{array}$ & $* * *$ & $\begin{array}{r}0.012 \\
(0.000)\end{array}$ & $* * *$ & $\begin{array}{r}0.011 \\
(0.000)\end{array}$ & $* * *$ & $\begin{array}{r}0.002 \\
(0.002)\end{array}$ & $* * *$ \\
\hline Target cash ratio & $\begin{array}{r}0.021 \\
(0.788)\end{array}$ & & $\begin{array}{r}0.103 \\
(0.176)\end{array}$ & & $\begin{array}{r}-0.035 \\
(0.512)\end{array}$ & & $\begin{array}{r}0.035 \\
(0.631)\end{array}$ & & $\begin{array}{r}0.028 \\
(0.727)\end{array}$ & & $\begin{array}{r}-0.034 \\
(0.545)\end{array}$ & & $\begin{array}{l}-0.112 \\
(0.578)\end{array}$ & & $\begin{array}{r}-0.101 \\
(0.621)\end{array}$ & & $\begin{array}{r}-0.025 \\
(0.653)\end{array}$ & \\
\hline Acquirer cash ratio & $\begin{array}{r}-0.075 \\
0.556\end{array}$ & & $\begin{array}{r}-0.142 \\
-0.244\end{array}$ & & $\begin{array}{r}-0.052 \\
(0.495)\end{array}$ & & $\begin{array}{l}-0.037 \\
0.078)\end{array}$ & & $\begin{array}{r}-0.015 \\
0.905)\end{array}$ & & $\begin{array}{r}-0.034 \\
(0.659)\end{array}$ & & $\begin{array}{l}-0.186 \\
0.472)\end{array}$ & & $\begin{array}{r}-0.193 \\
(0.458)\end{array}$ & & $\begin{array}{l}-0.034 \\
0.667)\end{array}$ & \\
\hline Target debt ratio & $\begin{array}{r}(0.556) \\
0.026 \\
(0.540)\end{array}$ & & $\begin{array}{r}(0.244) \\
-0.032 \\
(0.516)\end{array}$ & & $\begin{array}{r}(0.495) \\
0.079 \\
(0.037)\end{array}$ & $* *$ & $\begin{array}{r}(0.738) \\
0.046 \\
(0.267)\end{array}$ & & $\begin{array}{r}(0.005) \\
0.028 \\
(0.538)\end{array}$ & & $\begin{array}{r}(0.039) \\
0.072 \\
(0.064)\end{array}$ & $*$ & $\begin{array}{r}(0.4 / 2) \\
0.017 \\
(0.791)\end{array}$ & & $\begin{array}{r}(0.458) \\
0.012 \\
(0.855)\end{array}$ & & $\begin{array}{r}(0.00 /) \\
0.070 \\
(0.064)\end{array}$ & $* *$ \\
\hline Acquirer debt ratio & $\begin{array}{l}-0.073 \\
(0.426)\end{array}$ & & $\begin{array}{r}0.004 \\
(0.966)\end{array}$ & & $\begin{array}{r}-0.044 \\
(0.386)\end{array}$ & & $\begin{array}{r}-0.081 \\
(0.269)\end{array}$ & & $\begin{array}{r}-0.117 \\
(0.184)\end{array}$ & & $\begin{array}{l}-0.072 \\
(0.173)\end{array}$ & & $\begin{array}{r}0.045 \\
(0.818)\end{array}$ & & $\begin{array}{r}0.032 \\
(0.870)\end{array}$ & & $\begin{array}{r}-0.067 \\
(0.208)\end{array}$ & \\
\hline Target profitability & $\begin{array}{r}0.113 \\
(0.136)\end{array}$ & & $\begin{array}{r}0.080 \\
(0.334)\end{array}$ & & $\begin{array}{r}-0.028 \\
(0.567)\end{array}$ & & $\begin{array}{r}0.083 \\
(0.197)\end{array}$ & & $\begin{array}{r}0.085 \\
(0.253)\end{array}$ & & $\begin{array}{r}-0.022 \\
(0.666)\end{array}$ & & $\begin{array}{r}-0.129 \\
(0.461)\end{array}$ & & $\begin{array}{r}-0.101 \\
(0.553)\end{array}$ & & $\begin{array}{r}-0.003 \\
(0.958)\end{array}$ & \\
\hline Acquirer profitability & -0.092 & & 0.035 & & 0.064 & & -0.067 & & $\begin{array}{r}-0.045 \\
-0.708\end{array}$ & & 0.125 & & 0.466 & & 0.418 & & 0.143 & * \\
\hline Target R\&D & $\begin{array}{r}(0.413) \\
0.094 \\
(0.543)\end{array}$ & & $\begin{array}{r}(0.754) \\
0.282 \\
(0.071)\end{array}$ & * & $\begin{array}{r}(0.391) \\
-0.071 \\
(0.448)\end{array}$ & & $\begin{array}{r}(0.499) \\
0.050 \\
(0.711)\end{array}$ & & $\begin{array}{r}(0.708) \\
0.074 \\
(0.630)\end{array}$ & & $\begin{array}{r}(0.090) \\
-0.037 \\
(0.697)\end{array}$ & & $\begin{array}{c}(0.168) \\
-0.138 \\
(0.698)\end{array}$ & & $\begin{array}{c}(0.197) \\
-0.124 \\
(0.738)\end{array}$ & & $\begin{array}{r}(0.059) \\
-0.042 \\
(0.655)\end{array}$ & \\
\hline Acquirer R\&D & $\begin{array}{l}(0.345) \\
-0.155\end{array}$ & & $\begin{array}{l}(0.071) \\
-0.163\end{array}$ & & $\begin{array}{r}(0.448) \\
0.219\end{array}$ & & $\begin{array}{r}(0 . / 11) \\
-0.014\end{array}$ & & -0.143 & & 0.270 & & 0.587 & & 0.578 & & 0.277 & \\
\hline
\end{tabular}




\begin{tabular}{|c|c|c|c|c|c|c|c|c|c|}
\hline \multirow{3}{*}{ Target industry value added } & $(0.658)$ & $(0.632)$ & $(0.203)$ & $(0.962)$ & $(0.665)$ & $(0.117)$ & $(0.292)$ & $(0.298)$ & $(0.109)$ \\
\hline & 0.043 & 0.057 & $\begin{array}{l}0.019 \\
-0.019\end{array}$ & 0.079 & 0.077 & 0.010 & 0.205 & 0.201 & 0.015 \\
\hline & $(0.766)$ & $(0.689)$ & $(0.851)$ & $(0.538)$ & $(0.588)$ & $(0.923)$ & $(0.423)$ & $(0.434)$ & $(0.886)$ \\
\hline \multirow[t]{2}{*}{ Acquirer industry value added } & 0.033 & 0.035 & 0.086 & 0.086 & 0.017 & 0.103 & -0.112 & -0.119 & 0.095 \\
\hline & $(0.796)$ & $(0.793)$ & $(0.374)$ & $(0.489)$ & $(0.898)$ & $(0.303)$ & $(0.587)$ & $(0.569)$ & $(0.336)$ \\
\hline \multirow[t]{2}{*}{ Target stdev industry profitability } & 0.001 & 0.001 & 0.001 & 0.001 & 0.001 & 0.001 & 0.002 & 0.001 & 0.001 \\
\hline & $(0.419)$ & $(0.376)$ & $(0.382)$ & $(0.088)$ & $(0.370)$ & $(0.294)$ & $(0.369)$ & $(0.385)$ & $(0.322)$ \\
\hline \multirow[t]{2}{*}{ Acquirer stdev industry profitability } & -0.000 & -0.001 & -0.000 & -0.000 & -0.000 & -0.000 & -0.003 & -0.003 & -0.000 \\
\hline & $(0.631)$ & $(0.509)$ & $(0.647)$ & $(0.786)$ & $(0.740)$ & $(0.563)$ & $(0.143)$ & $(0.157)$ & $(0.608)$ \\
\hline Year dummies & Yes & Yes & Yes & Yes & Yes & Yes & Yes & Yes & $\mathrm{Yes}$ \\
\hline $\mathbf{N}$ & 352 & 352 & 661 & 416 & 352 & 661 & 144 & 144 & 661 \\
\hline Adjusted R-squared & 0.306 & 0.266 & 0.336 & $\begin{array}{r}410 \\
0.321\end{array}$ & 0.292 & $\begin{array}{r}001 \\
0.320\end{array}$ & $\begin{array}{l}144 \\
0.202\end{array}$ & 0.198 & 0.323 \\
\hline
\end{tabular}




\section{Table IX: Correlation between proxies for information asymmetry and uncertainty and measures of bargaining power and relative misvaluation}

This table reports the pairwise correlation coefficients between our measures of target information asymmetry and our proxies for bargaining power (a dummy variable capturing whether rival bidders have been identified, the number of rival bidders, a dummy capturing whether targets accept a termination fee while bidders do not and a dummy equaling one for target initiated deals), and between our measures of bidder information asymmetry/uncertainty and relative bidder versus target misvaluation. The following proxies for information asymmetry are considered: Composite asymmetric information index 1 (=composite index including the inverse of normalized relative analyst coverage, normalized analyst forecast dispersion, normalized analyst forecast error and the inverse of normalized relative media coverage), Composite asymmetric information index 2 (=composite index including the inverse of normalized relative analyst coverage, normalized analyst forecast dispersion, normalized analyst forecast error, the inverse of normalized relative media coverage and normalized firm size), the inverse of firm size, the inverse of relative analyst coverage (=number of financial analysts/firm size), analyst forecast error (=absolute value of the difference between median EPS estimate and actual value/stock price), analyst forecast dispersion (=standard deviation EPS/stock price) and the inverse of relative media coverage (=number of Factiva articles in pre-M\&A year/firm size). The degree of uncertainty is captured by implied and idiosyncratic stock return volatility as well as a composite index of both normalized volatility measures. $p$-values are reported in parentheses. $* * * * *$ and $*$ indicate significance at the 1,5 , and $10 \%$ levels, respectively.

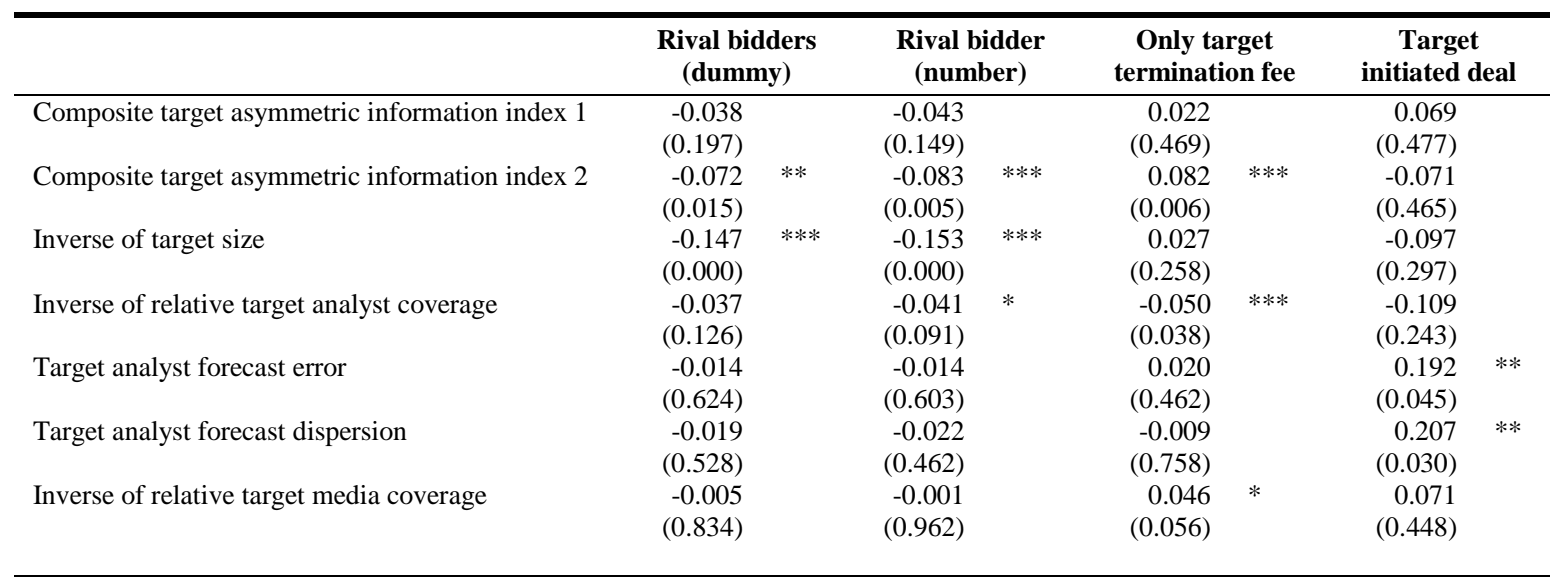

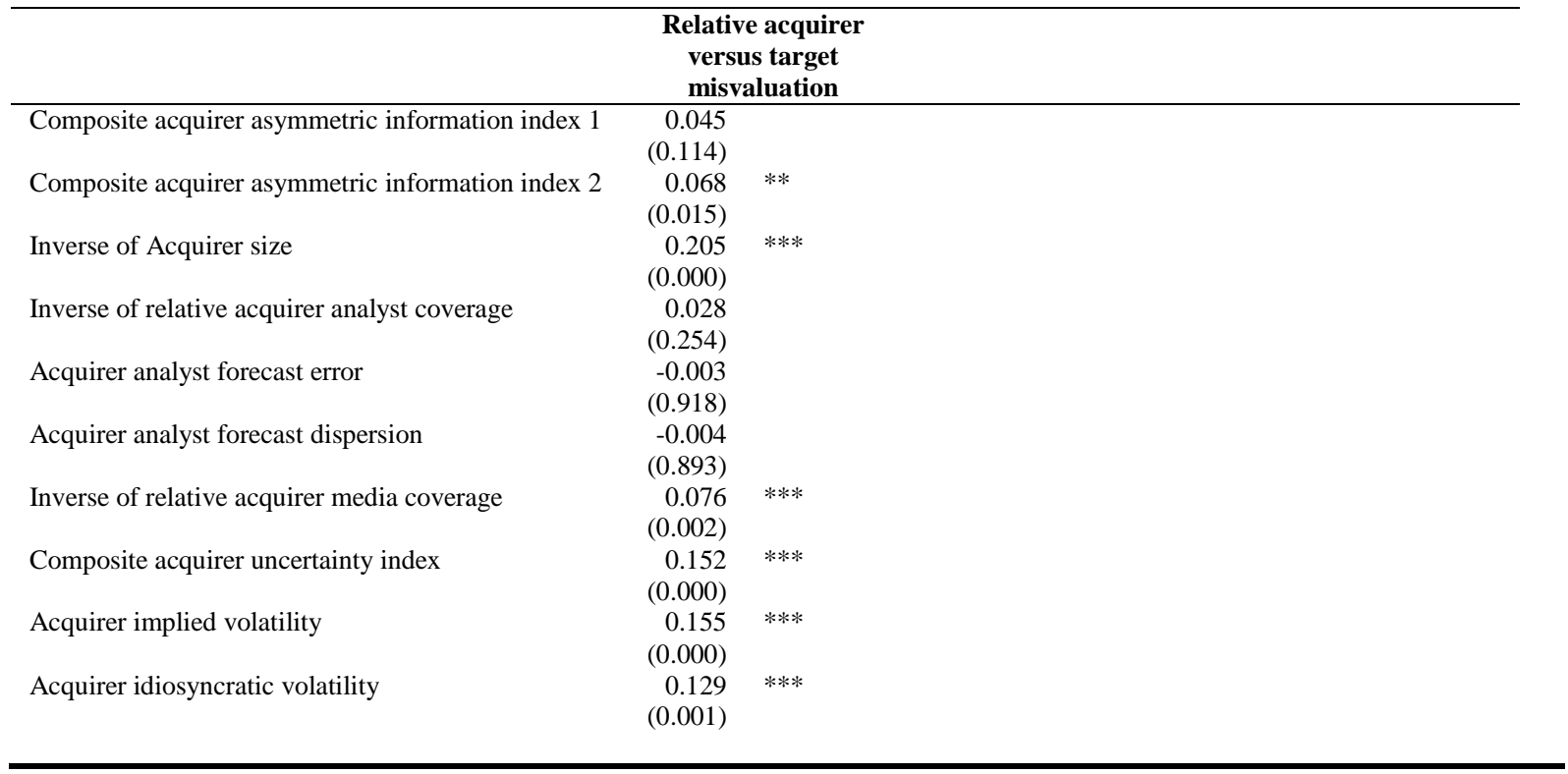




\section{Appendix A: Definitions of explanatory variables}

This table presents an overview of the detailed definitions of the various explanatory variables included across the different tables in the paper.

\begin{tabular}{ll}
\hline Explanatory variable & \multicolumn{1}{c}{ Definition } \\
$\begin{array}{l}\text { Proxies for information asymmetry } \\
\begin{array}{l}\text { Composite asymmetric } \\
\text { information index } 1\end{array}\end{array}$ & $\begin{array}{l}\text { Composite index including the inverse of normalized relative analyst } \\
\text { coverage, normalized analyst forecast dispersion, normalized analyst forecast } \\
\text { error and the inverse of normalized relative media coverage }\end{array}$ \\
$\begin{array}{l}\text { Composite asymmetric } \\
\text { information index } 2\end{array}$ & $\begin{array}{l}\text { Composite index including the inverse of normalized relative analyst } \\
\text { error, the inverse of normalized relative media coverage and normalized firm } \\
\text { size }\end{array}$ \\
Number of financial analyst recommendations for the last month of the fiscal \\
year preceding the M\&A announcement, scaled by firm size
\end{tabular}

\section{Proxies for uncertainty Composite uncertainty index Implied volatility}

Idiosyncratic volatility

\author{
Control variables \\ Target size/Acquirer size \\ Stock \\ Tender offer \\ Hostile offer \\ Industry-related offer \\ Toehold \\ $M / B$ \\ Cash ratio \\ Debt ratio \\ Profitability \\ $R \& D$ \\ $S \& P$ dummy \\ Industry value added
}

Stdev industry profitability

Median industry analyst coverage
Composite index including implied and idiosyncratic stock return volatility Median daily implied volatility from 80 days until 51 days before the M\&A announcement (average between ATM call and ATM put options)

Standard deviation of the market-adjusted residuals of daily stock returns during a 200-day estimation window (250 days until 51 days before the announcement)

Target size divided by acquirer size (pre-M\&A year)

Dummy equalling one for full-stock offers

Dummy equalling one for tender offers

Dummy equalling one for hostile offers

Dummy equalling one for industry-related offers (4-digit US SIC level)

Stake in the target firm held by the acquirer before the acquisition offer

Market-to-book ratio of equity (pre-M\&A year)

Cash and cash equivalents/total assets (pre-M\&A year)

Total debt/total assets (pre-M\&A year)

EBITDA/total assets (pre-M\&A year)

R\&D expenses/total assets (pre-M\&A year)

Dummy equalling one for firms included in the S\&P500

Industry value added/total output (using IO industry codes in 2002 Use and Make tables of US Bureau of Economic Analysis)

Standard deviation of EBITDA/total assets in a four-digit US SIC industry (pre-M\&A year)

Median financial analyst recommendations in a four-digit US SIC industry (pre-M\&A year) 


\section{Appendix B: Method of payment - Alternative model specifications}

This table reports the results of logit (All cash $=1$ ), ordered probit (All cash $=2$; Mixed $=1$; All stock $=0$ ) and OLS regressions (\% of cash). The following proxies for target and acquirer information (a)symmetry are considered as explanatory variables in the model. information asymmetry index 1 (= composite index including the inverse of normalized relative analyst and media coverage), information asymmetry index 2 (composite index including the inverse of normalized relative analyst coverage, relative media coverage and firm size), information asymmetry index 3 (=composite index including the inverse of normalized relative analyst coverage, relative media coverage, firm size, and normalized analyst forecast dispersion and analyst forecast error), information asymmetry index 4 (=composite index including inverse of normalized relative analyst coverage, relative media coverage, firm size, and normalized analyst forecast dispersion, analyst forecast error and implied volatility), relative analyst coverage (=number of financial analysts/irm size), analyst forecast dispersion (-standard deviation ETS/stock price), analyst forecast error (=absolute value of the difference between median ESS estimate and actual value/stock price), relative media coverage (=number of Factiva articles in pre-M\&A year/firm size), implied volatility, firm size (=natural logarithm of total assets). The control variables include the relative size of target versus bidder, dummies capturing respectively whether it is a tender, an hostile or an industry-related offer (at 4-digit SIC level), the acquirer's toehold in the target, the target's and acquirer's market-to-book ratio of equity (M/B), cash ratio $(=$ cash and cash equivalents/total assets), debt ratio $(=$ total

\begin{tabular}{|c|c|c|c|c|c|c|c|c|c|c|c|c|c|c|c|c|c|c|}
\hline \multirow[b]{2}{*}{ Constant } & \multicolumn{2}{|c|}{$\begin{array}{c}\text { Logit } \\
(1)\end{array}$} & \multicolumn{2}{|c|}{$\begin{array}{l}\text { Logit } \\
(2)\end{array}$} & \multicolumn{2}{|c|}{$\begin{array}{c}\text { Logit } \\
\text { (3) }\end{array}$} & \multicolumn{2}{|c|}{$\begin{array}{l}\text { Ordered Probit } \\
\text { (4) }\end{array}$} & \multicolumn{2}{|c|}{$\begin{array}{c}\text { Ordered Probit } \\
\text { (5) }\end{array}$} & \multicolumn{2}{|c|}{$\begin{array}{c}\text { Ordered Probit } \\
(6)\end{array}$} & \multicolumn{2}{|c|}{$\begin{array}{c}\text { OLS } \\
(7)\end{array}$} & \multicolumn{2}{|c|}{$\begin{array}{c}\text { OLS } \\
(8)\end{array}$} & \multicolumn{2}{|c|}{$\begin{array}{c}\text { OLS } \\
(9)\end{array}$} \\
\hline & $\begin{array}{l}-1.645 \\
(0.115)\end{array}$ & & $\begin{aligned}-0.115 \\
(0.884)\end{aligned}$ & & $\begin{array}{l}-2.686 \\
(0.172)\end{array}$ & & $\begin{array}{r}0.836 \\
(0.084)\end{array}$ & * & $\begin{array}{r}0.061 \\
(0.872)\end{array}$ & & $\begin{array}{r}0.247 \\
(0.741)\end{array}$ & & $\begin{array}{r}0.219 \\
(0.071)\end{array}$ & * & $\begin{array}{r}0.387 \\
(0.000)\end{array}$ & $* * *$ & $\begin{array}{r}0.443 \\
(0.023)\end{array}$ & $* *$ \\
\hline Constant2 & & & & & & & $\begin{array}{r}1.941 \\
(0.000)\end{array}$ & **** & $\begin{array}{r}1.148 \\
(0.003)\end{array}$ & $* * *$ & $\begin{array}{r}1.689 \\
(0.027)\end{array}$ & ** & & & & & & \\
\hline Target composite asymmetric information index 1 & $\begin{array}{r}0.676 \\
(0.004)\end{array}$ & $* * *$ & & & & & $\begin{array}{r}0.275 \\
(0.014)\end{array}$ & *** & & & & & $\begin{array}{r}0.083 \\
(0.008)\end{array}$ & $* * *$ & & & & \\
\hline Target composite asymmetric information index 2 & & & $\begin{array}{r}1.075 \\
(0.000)\end{array}$ & $* * *$ & & & & & $\begin{array}{r}0.3805 \\
(0.001)\end{array}$ & $* * *$ & & & & & $\begin{array}{r}0.138 \\
(0.000)\end{array}$ & $* * *$ & & \\
\hline Target uncertainty index & & & & & $\begin{array}{l}-1.071 \\
(0.037)\end{array}$ & $* * *$ & & & & & $\begin{array}{r}-0.263 \\
(0.110)\end{array}$ & & & & & & $\begin{array}{r}-0.073 \\
(0.080)\end{array}$ & * \\
\hline Target size & $\begin{array}{l}-0.577 \\
(0.000)\end{array}$ & $* * *$ & & & $\begin{array}{l}-1.150 \\
(0.000)\end{array}$ & $* * *$ & $\begin{array}{r}-0.202 \\
(0.000)\end{array}$ & **** & & & $\begin{array}{r}-0.321 \\
(0.001)\end{array}$ & $* * *$ & $\begin{array}{r}-0.053 \\
(0.000)\end{array}$ & $* * *$ & & & $\begin{array}{r}-0.065 \\
(0.005)\end{array}$ & $* * *$ \\
\hline Acquirer composite asymmetric information index 1 & $\begin{array}{r}0.256 \\
(0.388)\end{array}$ & & & & & & $\begin{array}{r}0.182 \\
(0.246)\end{array}$ & & & & & & $\begin{array}{r}0.061 \\
(0.123)\end{array}$ & & & & & \\
\hline Acquirer composite asymmetric information index 2 & & & $\begin{array}{r}-0.731 \\
(0.041)\end{array}$ & $* *$ & & & & & $\begin{array}{l}-0.322 \\
(0.045)\end{array}$ & ** & & & & & $\begin{array}{r}-0.100 \\
(0.001)\end{array}$ & $* * *$ & & \\
\hline Target uncertainty index & & & & & $\begin{array}{l}-1.504 \\
(0.002)\end{array}$ & **** & & & & & $\begin{array}{r}-0.510 \\
(0.001)\end{array}$ & $* * *$ & & & & & $\begin{array}{r}-0.110 \\
(0.003)\end{array}$ & $* * *$ \\
\hline Acquirer size & $\begin{array}{r}0.605 \\
(0.000)\end{array}$ & $* * *$ & & & $\begin{array}{r}0.792 \\
(0.001)\end{array}$ & $* * *$ & $\begin{array}{r}0.252 \\
(0.000)\end{array}$ & $* * *$ & & & $\begin{array}{r}0.218 \\
(0.009)\end{array}$ & $* * *$ & $\begin{array}{r}0.062 \\
(0.000)\end{array}$ & $* * *$ & & & $\begin{array}{r}0.027 \\
(0.126)\end{array}$ & \\
\hline <Control variables included $>$ & & & & & & & & & & & & & & & & & & \\
\hline Year dummies & Yes & & Yes & & Yes & & Yes & & Yes & & Yes & & Yes & & Yes & & Yes & \\
\hline $\mathbf{N}$ & 922 & & 922 & & 402 & & 922 & & 922 & & 402 & & 845 & & 845 & & 353 & \\
\hline $\begin{array}{l}\text { Mc Fadden R-squared } \\
\text { Pseudo R-squared }\end{array}$ & 0.463 & & 0.443 & & 0.613 & & 0.316 & & 0.305 & & 0.354 & & & & & & & \\
\hline Adjusted R-squared & & & & & & & & & & & & & 0.497 & & 0.488 & & 0.523 & \\
\hline
\end{tabular}




\section{Appendix C: Two-stage regression models: instrumenting analyst coverage}

This table reports the results of two-stage iv probit (dependent variable equals one for all cash payments) and two-stage iv least-squares (dependent variables equal acquirer CAR over the window $[-1,+1]$ and acquirer relative returns). The following instrumental variables for analyst coverage are used: the median number of analysts in the target and acquirer industry and a dummy capturing target and acquirer inclusion in the S\&P 500. The following explanatory variables are included in the model: relative analyst coverage (=number of financial analysts/firm size), target size, acquirer size, relative size of target versus bidder, dummies capturing respectively whether it is a tender, an hostile or an industry-related offer (at 4-digit SIC level), the acquirer's toehold in the target, the target's and acquirer's market-to-book ratio of equity (M/B), cash ratio (= cash and cash equivalents/total assets), debt ratio (= total debt/total assets), profitability (= EBITDA/total assets), R\&D (= R\&D expenses/total assets), industry value added (= value added/total output), and the standard deviation of profitability in the target's and acquirer's industry. t-statistics are calculated using White heteroscedasticity-consistent standard errors. p-values are reported in parentheses.***, $* *$ and $*$ indicate significance at the 1,5 , and $10 \%$ levels, respectively.

\begin{tabular}{|c|c|c|c|c|c|c|c|c|c|c|}
\hline & \multicolumn{6}{|c|}{ Two-stage iv probit regression } & \multicolumn{4}{|c|}{ Two-stage iv least squares regression } \\
\hline & \multicolumn{2}{|c|}{ First stage } & \multicolumn{2}{|c|}{ First stage } & \multicolumn{2}{|c|}{ Second stage } & \multicolumn{2}{|c|}{ Second stage } & \multicolumn{2}{|c|}{ Second stage } \\
\hline & \multicolumn{2}{|c|}{$\begin{array}{c}\text { Relative target } \\
\text { coverage } \\
\text { (1) }\end{array}$} & \multicolumn{2}{|c|}{$\begin{array}{l}\text { Relative acquirer } \\
\text { coverage } \\
\text { (2) }\end{array}$} & \multicolumn{2}{|c|}{$\underset{(3)}{\text { All cash }}=\mathbf{1}$} & \multicolumn{2}{|c|}{$\begin{array}{c}\text { Acquirer CAR } \\
{[-1,+1]} \\
(4)\end{array}$} & \multicolumn{2}{|c|}{$\begin{array}{l}\text { Acquirer relative } \\
\text { return } \\
(5)\end{array}$} \\
\hline Constant & $\begin{aligned}-1.176 \\
(0.000)\end{aligned}$ & **** & $\begin{array}{r}-0.919 \\
(0.000)\end{array}$ & $* * *$ & $\begin{aligned}-2.348 \\
(0.018)\end{aligned}$ & $* * *$ & $\begin{array}{r}0.027 \\
(0.597)\end{array}$ & & $\begin{array}{r}-0.042 \\
(0.409)\end{array}$ & \\
\hline Median industry analyst coverage target & $\begin{array}{r}-0.002 \\
(0.920)\end{array}$ & & $\begin{array}{r}0.002 \\
(0.915)\end{array}$ & & & & & & & \\
\hline Median industry analyst coverage acquirer & $\begin{array}{r}0.019 \\
(0.227)\end{array}$ & & $\begin{array}{r}0.033 \\
(0.099)\end{array}$ & $*$ & & & & & & \\
\hline Target S\&P dummy & $\begin{array}{r}0.210 \\
(0.002)\end{array}$ & $* * *$ & $\begin{array}{r}0.060 \\
(0.492)\end{array}$ & & & & & & & \\
\hline Acquirer S\&P dummy & $\begin{array}{r}0.084 \\
(0.059)\end{array}$ & $*$ & $\begin{array}{r}0.598 \\
(0.000)\end{array}$ & $* * *$ & & & & & & \\
\hline Relative target analyst coverage (instrumented) & & & & & $\begin{array}{r}-1.363 \\
(0.117)\end{array}$ & & $\begin{array}{r}-0.013 \\
(0.749)\end{array}$ & & $\begin{array}{r}-0.037 \\
(0.353)\end{array}$ & \\
\hline Target size & $\begin{array}{r}0.243 \\
(0.000)\end{array}$ & $* * *$ & $\begin{array}{r}-0.001 \\
(0.534)\end{array}$ & & $\begin{array}{r}0.016 \\
(0.945)\end{array}$ & & $\begin{array}{r}-0.006 \\
(0.583)\end{array}$ & & $\begin{array}{r}-0.007 \\
(0.534)\end{array}$ & \\
\hline Stock & & & & & & & $\begin{array}{r}-0.050 \\
(0.001)\end{array}$ & $* * *$ & $\begin{array}{r}0.011 \\
(0.478)\end{array}$ & \\
\hline Relative acquirer analyst coverage*stock (instrumented) & & & & & & & $\begin{array}{r}0.025 \\
(0.007)\end{array}$ & $* * *$ & $\begin{array}{r}-0.009 \\
(0.346)\end{array}$ & \\
\hline Relative acquirer analyst coverage (instrumented) & & & & & $\begin{array}{r}0.037 \\
(0.890)\end{array}$ & & $\begin{array}{r}0.002 \\
(0.866)\end{array}$ & & $\begin{array}{r}0.042 \\
(0.003)\end{array}$ & $* * *$ \\
\hline Acquirer size & $\begin{array}{r}0.040 \\
(0.003)\end{array}$ & $* * *$ & $\begin{array}{r}0.155 \\
(0.000)\end{array}$ & & $\begin{array}{r}0.366 \\
(0.000)\end{array}$ & $* * *$ & $\begin{array}{r}0.001 \\
(0.868)\end{array}$ & & $\begin{array}{r}0.004 \\
(0.187)\end{array}$ & \\
\hline$<$ Control variables included $>$ & & & & & & & & & & \\
\hline Year dummies & Yes & & Yes & & Yes & & Yes & & Yes & \\
\hline $\begin{array}{l}\text { N } \\
\text { Adiusted R-souared }\end{array}$ & 1725 & & 1725 & & 1725 & & 1725 & & 1725 & \\
\hline $\begin{array}{l}\text { Wald Chi }{ }^{2} \\
(p \text {-value) }\end{array}$ & 0.401 & & 0.592 & & $\begin{array}{r}524.35 \\
(0.000)\end{array}$ & & $\begin{array}{r}227.85 \\
(0.000)\end{array}$ & & $\begin{array}{r}270.09 \\
(0.000)\end{array}$ & \\
\hline $\begin{array}{l}\text { Wald test of exogeneity } \\
\text { ( } p \text {-value) }\end{array}$ & & & & & $\begin{array}{r}2.75 \\
(0.252)\end{array}$ & & & & & \\
\hline $\begin{array}{l}\text { Wu-Haussman test of exogeneity } \\
\text { ( } p \text {-value) }\end{array}$ & & & & & & & $\begin{array}{r}1.770 \\
(0.151)\end{array}$ & & $\begin{array}{r}2.700 \\
(0.044)\end{array}$ & \\
\hline
\end{tabular}

